\title{
COMPLETE
}

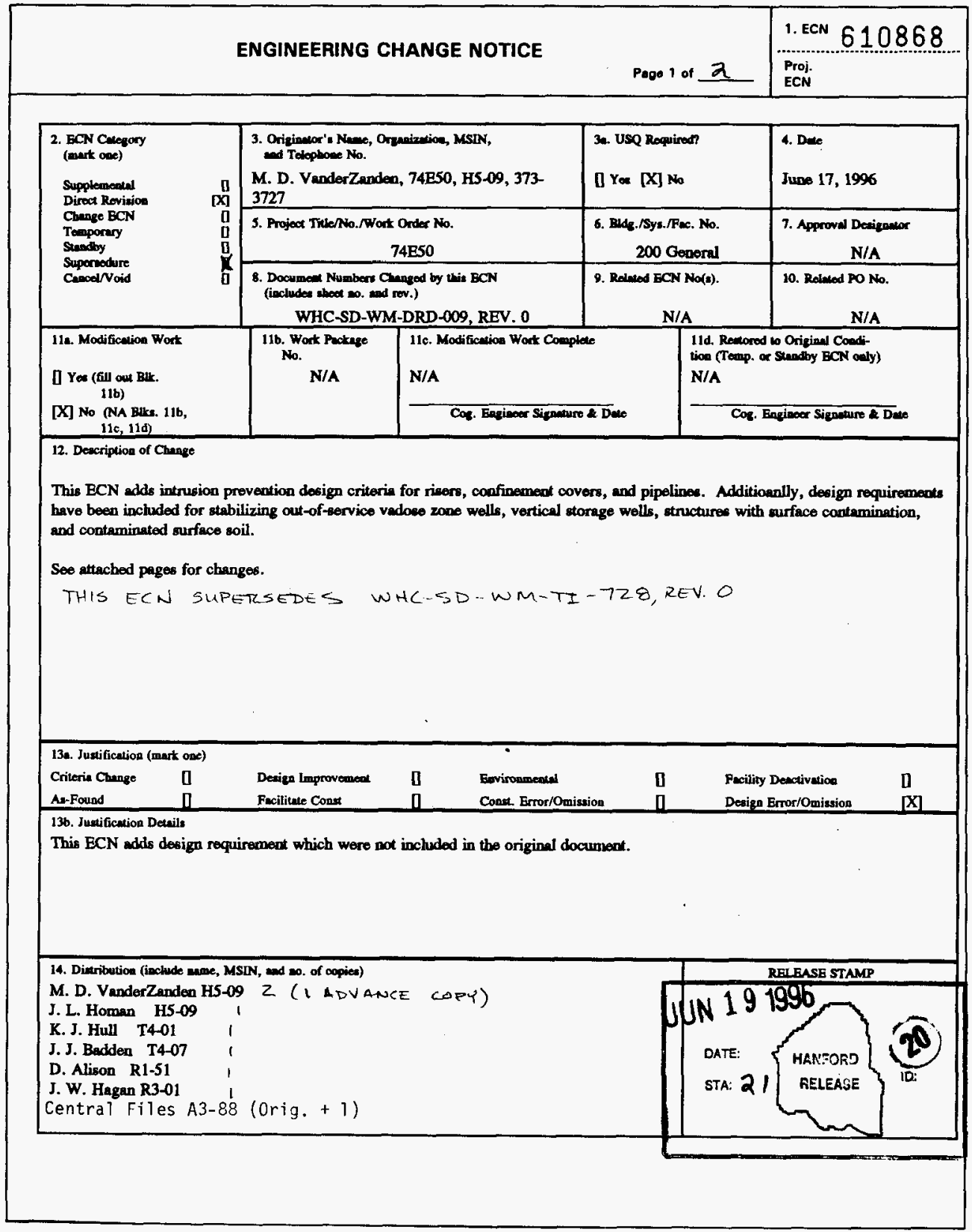




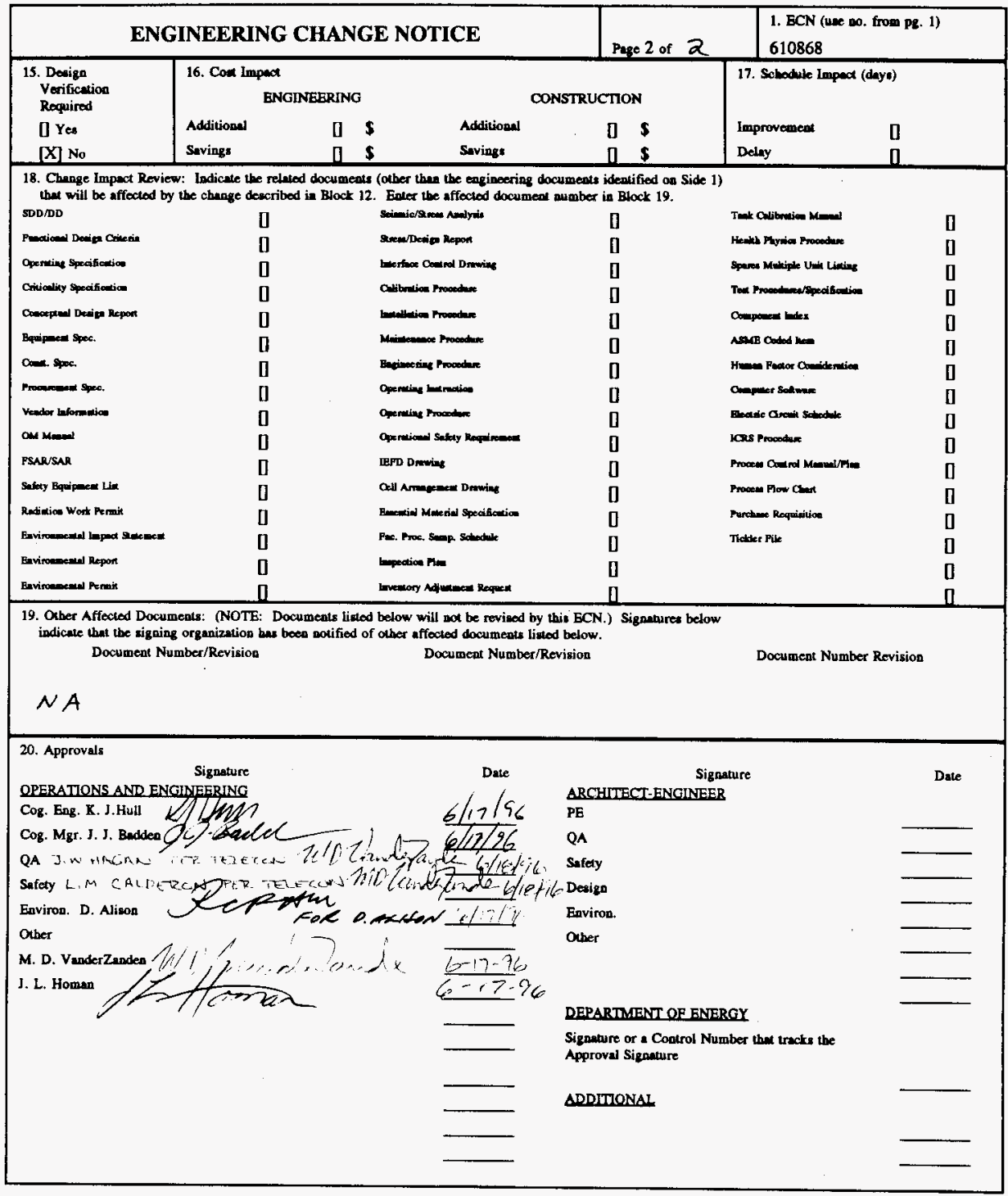




\section{Controlled, Clean, and Stable Design Requirements Document for Single-Shell Tank Farms}

M. D. VanderZanden

Westinghouse Hanford Co., Rich1and, WA 99352

U.S. Department of Energy Contract DE-AC06-87RL10930

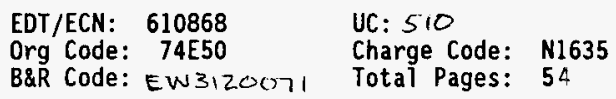

Key Words: Single-shell tank farms, inactive miscellaneous underground storage tanks, temperature monitoring, interstitial liquids, design requirements, waste level, intrusion prevention, gaseous effluent di scharge

Abstract: The Controlled, Clean, and Stable (CCS) Design Requirements Document (DRD) contains the technically defensible and traceable functions and requirements for maintaining the Single-Shell Tank Farms in a cost effective and safe interim end state. The CCS DRD functions and requirements constitute the project characteristics that are minimally sufficient to meet the CCS mission goals.

TRADEMARK DISCLAIMER. Reference herein to any specific comercisl product, process, or service by trade name, trademark, manufacturer, or otherwise, does not necessarily constitute or imply its endorsement, recomiendation, or favoring by the United States Government or any agency thereof or its contractors or subcontrectors.

Printed in the United states of Merica. To obtoin copies of this document, contact: WHC/BCS Document Control Services, P.0. Box 1970, Mailstop H6-08, Richland WA 99352, Phone (509) 372-2420; Fax (509) 376.6989 .
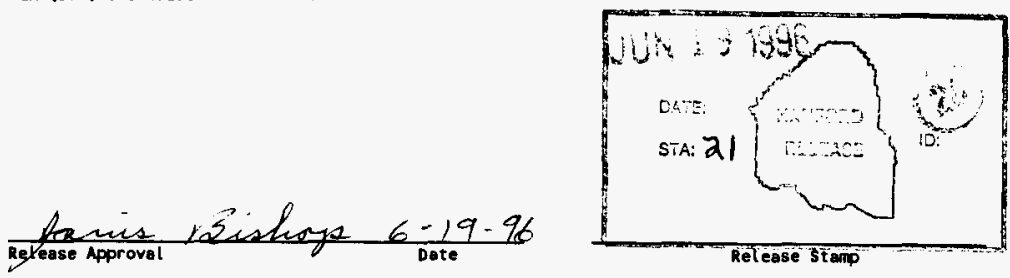

Approved for Public Release 


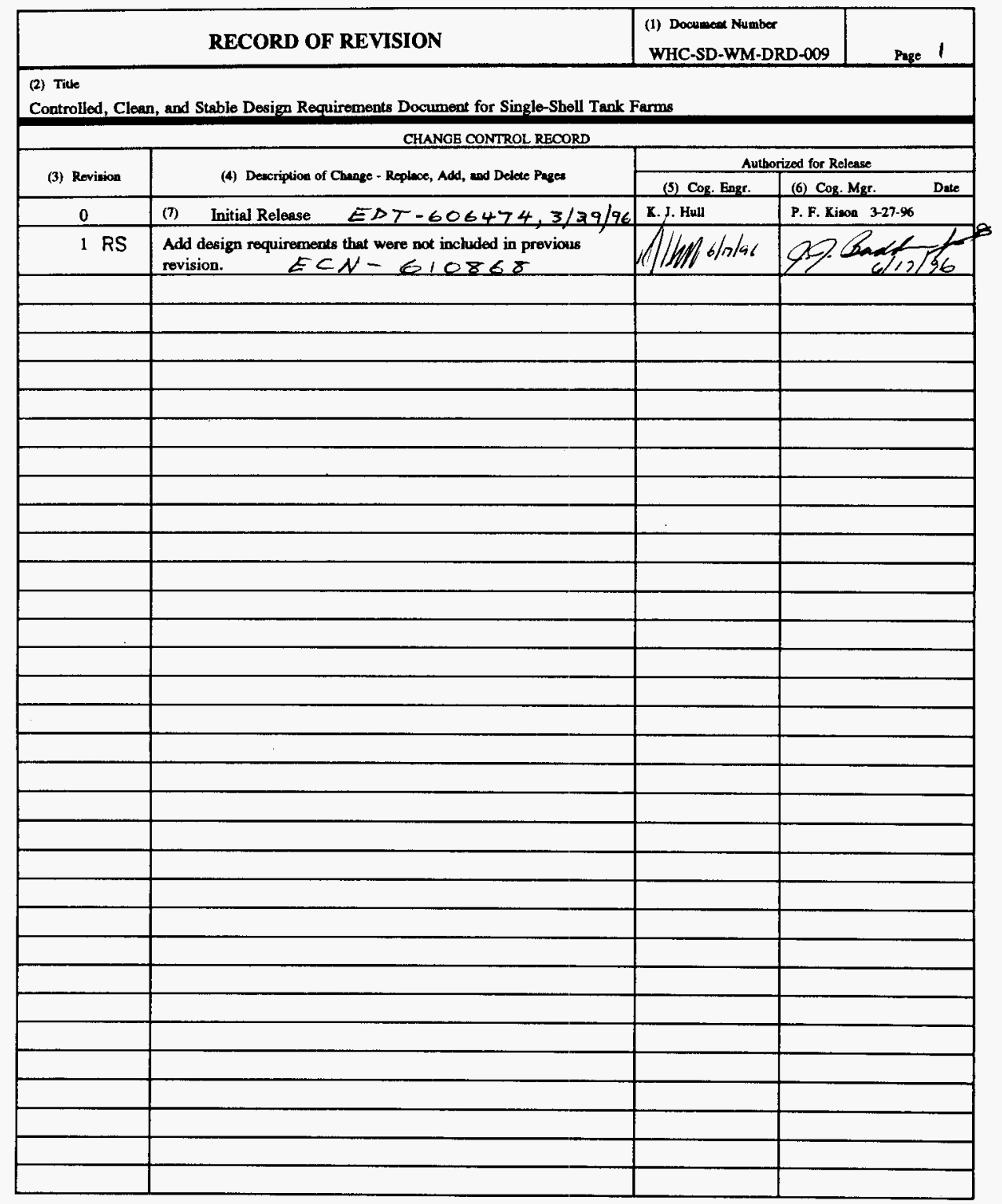




\title{
CONTROLLED, CLEAN, AND STABLE DESIGN REQUIREMENTS DOCUMENT FOR SINGLE-SHELL TANK FARMS
}

\author{
Prepared by: \\ Parsons Engineering Science, Inc. \\ Richland, Washington
}


The Tank Waste Remediation System (TWRS) mission is to store, treat, and immobilize highly radioactive waste in an environmentally safe, sound, and cost-effective manner. The U.S. Department of Energy (DOE) established the TWRS program to manage the 177 underground waste storage tanks at the Hanford Site. The TWRS program includes all activities related to receiving, storing, operating and maintaining, and disposing of all Hanford Site HighLevel Wastes (HLW).

The functions, requirements, interfaces, and architectures associated with the TWRS mission are contained within the TWRS Systems Engineering (SE) requirements database (RDD-100). This database is the result of the TWRS program level SE analysis. The Design Requirements Document (DRD) also documents the set of technically defensible, traceable functions and requirements (i.e., specifications) associated with the Controlled, Clean, and Stable (CCS) project.

The CCS DRD was developed from the CCS Mission Analysis (WHC 1995c) and from Tank Farm and system-level specification documents. The CCS DRD functions and requirements constitute the project characteristics that are minimally sufficient to meet the CCS Mission Goals, and are consistent with the overall TWRS Mission. The CCS DRD provides the following:

- Identifies the system level architecture;

- States the system architecture's required functionality and performance parameters;

- Identifies system architecture's boundaries and associated requirements in terms of interfaces with other system architectural element(s); and

- Identifies all technical, regulatory and policy constraints with which the system architecture must comply. 
WHC-SD-WM-DRD-009, Rev 1

This page intentionally left blank. 


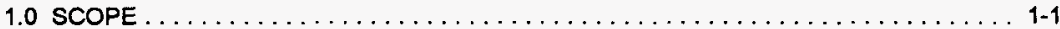

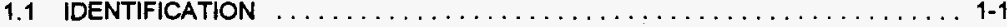

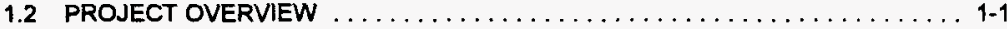

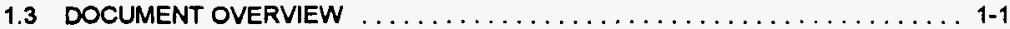

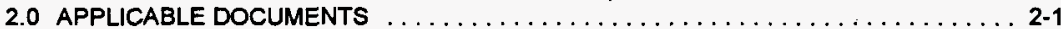

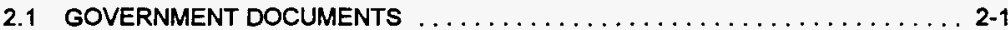

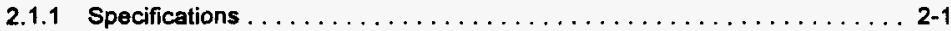

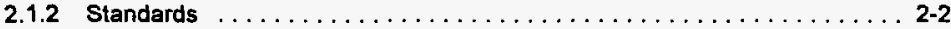

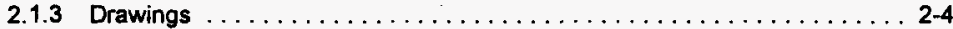

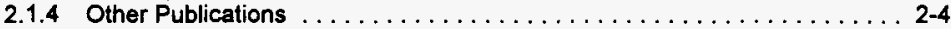

2.2 NON-GOVERNMENT DOCUMENTS $\ldots \ldots \ldots \ldots \ldots \ldots \ldots \ldots \ldots \ldots \ldots \ldots \ldots$

3.0 PROJECT FUNCTIONS AND REQUIREMENTS $\ldots \ldots \ldots \ldots \ldots \ldots \ldots \ldots \ldots \ldots \ldots$

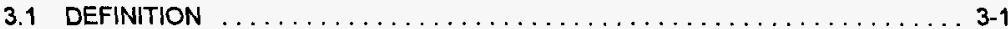

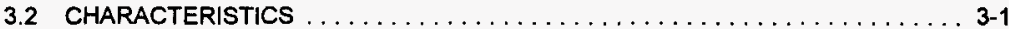

3.2.1 Performance Characteristics ..................... 3-5

3.2.1.1 Store Single-Shell Tank Wast . . . . . . . . . . . . . 3-5

3.2.1.1.1 Control Single-Shell Tank Waste Temperature ..... 3-5

3.2.1.1.2 Control Single-Shell Tank Waste Level . . . . . . . . . 3-6

3.2.1.1.3 Control Single-Shell Tank Intrusion . . . . . . . . . . 3-7

3.2.1.1.4 Control Single-Shell Tank Vapor-Space Pressure . . . . 3-8

3.2.1.1.5 Control Single-Shell Tank Gaseous Effluent Discharge . 3-9

3.2.1.2 Manage System Data IInformation . . . . . . . . . . . . . . 3-10

3.2.1.2.1 Data information Management $\ldots \ldots \ldots \ldots \ldots \ldots \ldots .3-10$

3.2.1.2.2 Performance Requirements . . . . . . . . . . 3-10

3.2.1.3 Manage Single-Shell Tank Farm Boundary . . . . . . . . . . 3-10

3.2.1.3.1 Isolate Single-Shell Tanks and Inactive Miscellaneous Underground Storage Tanks ............. 3-10

3.2.1.3.2 Manage Tank Farm Contaminated Equipment . . . . . 3-11

3.2.1.3.3 Cleanup and Stabilize Tank Farm Surface Soil . . . . 3 3-12

3.2.1.4 Relocate Single-Shell Tank Interstitial and Supernatant Liquids . . 3-12

3.2.1.4.1 Transfer 200 East Area Single-Shell Tank Liquid Waste to 200 East Area Double-Shell Tank Storage Location

3.2.1.4.2 Transfer 200 West Area Single-Shell Tank Liquid Waste to 200 West Area Double-Shell Tank Storage Location Location

3.2.1.5 Transfer Inactive Miscellaneous Underground Storage Tank Liquid Waste to a Double-Shell Tank Storage Location . . . . . . . . . . 3-13 3.2.1.5.1 Interim Stabilize Inactive Miscellaneous Underground Storage Tanks . . . . . . . . . . . . . . . . . 3-13

3.2.2 Project Relationships . . . . . . . . . . . . . . . . . . . $3-14$

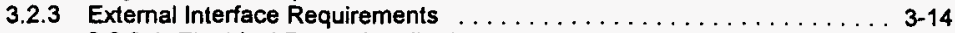

3.2.3.1 Electrical Power Distribution $\ldots \ldots \ldots \ldots \ldots \ldots \ldots \ldots . . \ldots \ldots$ 3-14

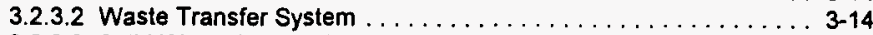

3.2.3.3 Solid Waste Disposal . . . . . . . . . . . . . . . . 3-14

3.2.3.4 Tank Characterization Project . . . . . . . . . . . . 3-14 


\title{
WHC-SD-WM-DRD-009, Rev 1
}

\author{
TABLE OF CONTENTS \\ (Continued)
}

3.2.3.5 Tank Monitoring and Control System . . . . . . . . . . . . . 3-15

3.2.3.6 Tank Farm Safety Program . . . . . . . . . . . . . . . 3-15

3.2.3.7 Authorization Basis Development Team . . . . . . . . . 3-15

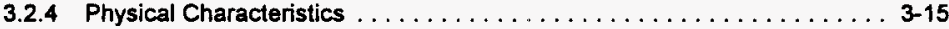

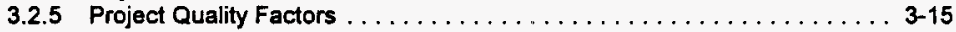

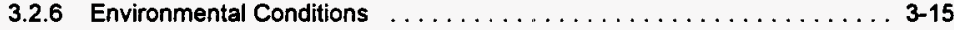

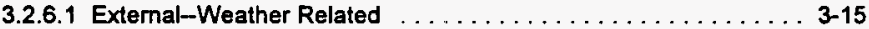

3.2.6.2 Extemal-Natural induced Forces . . . . . . . . . . . . . 3-16

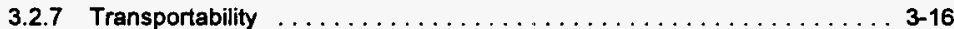

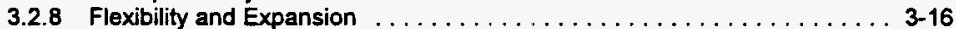

3.2.9 Portability ............................. 3-16

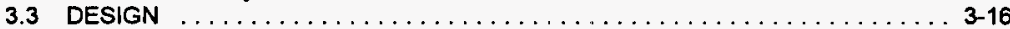

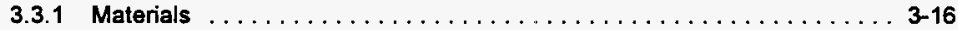

3.3.2 Electromagnetic Radiation $\ldots \ldots \ldots \ldots \ldots \ldots \ldots \ldots \ldots \ldots \ldots \ldots$ 3-17

3.3.3 Nameplates and Product Markings . . . . . . . . . . . . . . 3-17

3.3.3.1 Equipment Labeling . . . . . . . . . . . . . . . . 3-17

3.3.3.1.1 Electrical Equipment Labeling. . . . . . . . . . . . 3-17

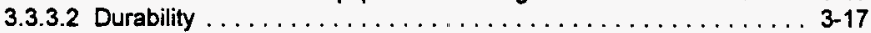

3.3.3.3 Legibility . . . . . . . . . . . . . . . . . . . . . . . . 3-17

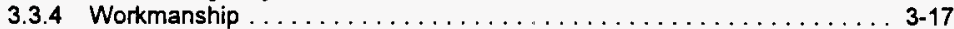

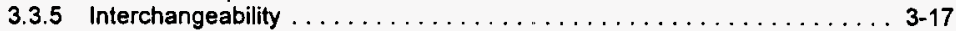

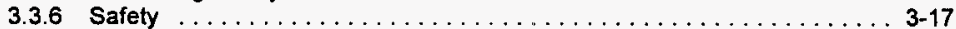

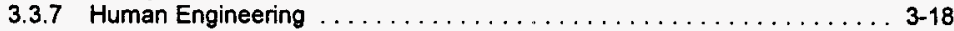

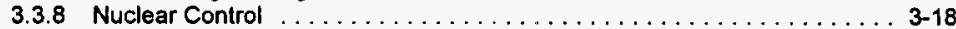

3.3.9 System Security . . . . . . . . . . . . . . . . . . . . . .

3.3.10 Government-Fumished Property Usage $\ldots \ldots \ldots \ldots \ldots \ldots \ldots$ 3-18

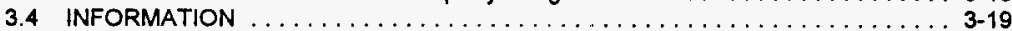

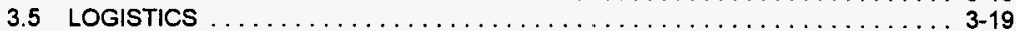

3.5.1 Maintenance .......................... 3-19

3.5.1.1 Fully-Remote Maintenance and Operation . . . . . . . . 3-19

3.5.1.2 Limited-Contact Maintenance and Operation . . . . . . . . . . 3-19

3.5.1.3 Full-Contact Maintenance and Operation . . . . . . . . . . 3-19

3.5.2 Waste Handling, Storage, and Disposal .............. 3-19

3.5.3 Transportation of Hazardous Materials . . . . . . . . . . . . 3-19

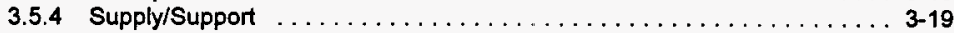

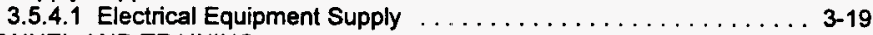

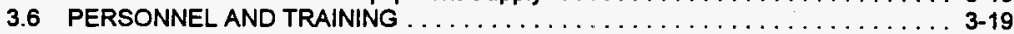

3.7 CHARACTERIZATION OF SUBORDINATE ELEMENTS $\ldots \ldots \ldots \ldots \ldots \ldots \ldots \ldots$

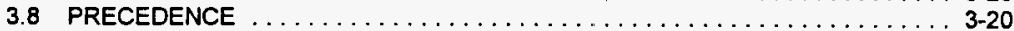

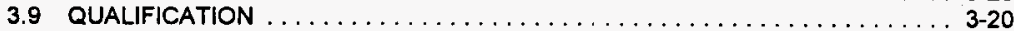

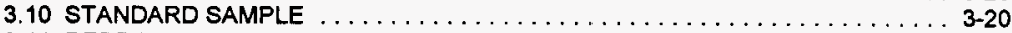

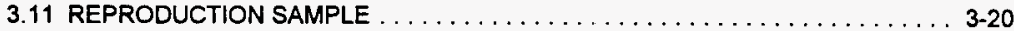

4.0 QUALITY ASSURANCE PROVISIONS $\ldots \ldots \ldots \ldots \ldots \ldots \ldots \ldots \ldots \ldots \ldots$

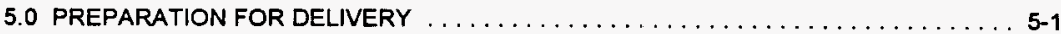




\section{TABLE OF CONTENTS}

(Continued)

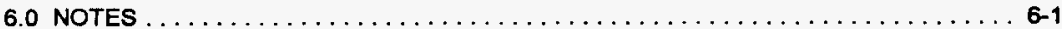

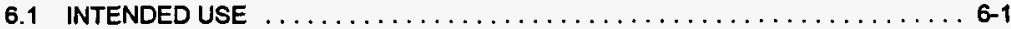

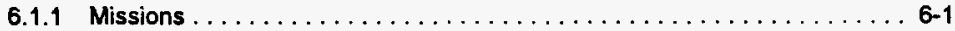

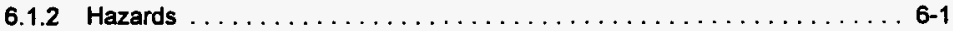

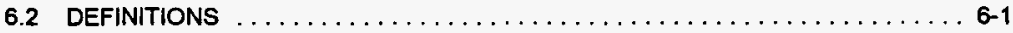

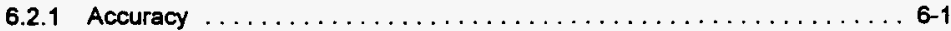

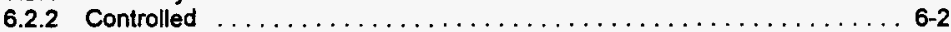

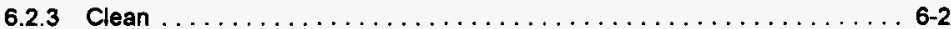

6.2.4 Drainable Interstitial ........................... 6-2

6.2 .5 Enraf $\ldots \ldots \ldots \ldots \ldots \ldots \ldots \ldots \ldots \ldots \ldots \ldots \ldots \ldots \ldots \ldots \ldots \ldots \ldots \ldots \ldots, 2$

6.2.6 High-Heat Tank . . . . . . . .

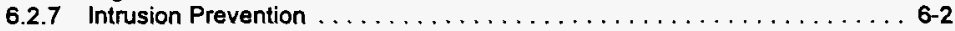

6.2 .8 Isokinetic . . . . . . . . . . . . .

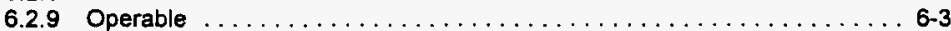

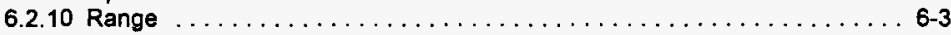

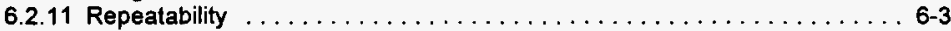

6.2 .12 Resolution .............................. 6-3

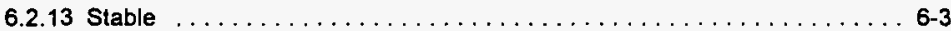

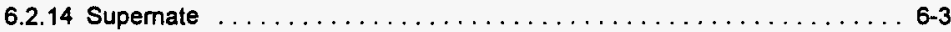

6.2.15 Thermocouple . . . . . . . . . . . . . . . . . . . . . . .

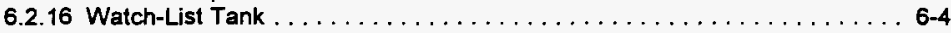

6.3 ABBREVIATIONS AND ACRONYMS $\ldots \ldots \ldots \ldots \ldots \ldots \ldots \ldots \ldots \ldots \ldots \ldots$

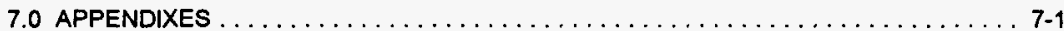

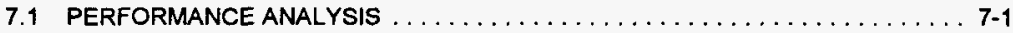

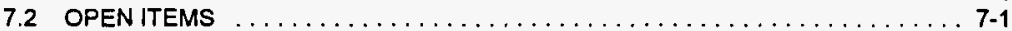

\section{FIGURE}

3-1. Manage Tank Waste Functional Hierarchy Applicable to the Single-Shell Tank

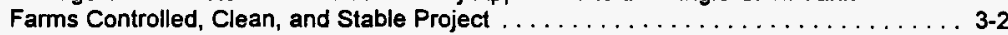

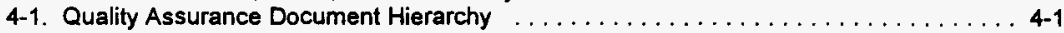

\section{TABLE}

7-1. Performance Analysis Comparing Specifications and the Performance Capabilities of the Systems and Equipment Being Used in the CCS Project 
WHC-SD-WM-DRD-009, Rev 1

This page intentionally left blank. 


\title{
1.0 SCOPE
}

\subsection{IDENTIFICATION}

\author{
Program: Tank Farm Remediation System \\ Project: Controlled, Clean, and Stable \\ System: 200 East and West Single-Shell Tank Farms
}

\subsection{PROJECT OVERVEW}

The Westinghouse Hanford Company (WHC) Tank Waste Remediation System (TWRS) program is responsible for providing safe storage, retrieval, treatment, and disposal of the Hanford Site High-Level Tank Wastes. The TWRS has established the Controlled, Clean, and Stable (CCS) project for the Single-Shell Tank (SST) Farms to reduce safety and environmental risks posed by the Tank Farms, and to reduce ongoing surveillance and maintenance costs for these same facilities. To accomplish this, the TWRS Tank Farm Transition Projects (TFTP) is transitioning the SST Farms to a safe interim end state, where only limited surveillance and maintenance will be required.

All SST farms will be turned over to the Retrieval Program for transition to a safe end state. As part of the tumover process, technical baseline documentation necessary to maintain each SST within its authorization basis will be prepared and given to the Retrieval Program. In addition to CCS documentation, technical baseline documentation packages will contain safety basis documentation, essential drawings, operating procedures, maintenance procedures, and surveillance procedures. Essential drawings and applicable procedures will be revised by the CCS Project to reflect the interim end state at tumover. Additionally, routinely recorded surveillance data, such as tank dome deflection, will be included in the turn over package.

\subsection{DOCUMENT OVERVIEW}

This document sets forth functional requirements, performance requirements, interface requirements, and design constraints for achieving CCS in the SST Farms. These requirements and constraints will adequately define CCS so that it supports the TWRS Mission from a performance standpoint. Section 3.2 identifies the overall CCS "Characteristics." Section 3.2.1 identifies the CCS specifications or "Performance Characteristics." Section 7.1 provides a comparison between these CCS specifications and the performance capabilities of the systems and equipment (i.e., design or architecture) that is being used in the CCS project. Section 7.2 identifies the open issues that must be resolved to meet the CCS specifications. 
WHC-SD-WM-DRD-009, Rev 1

This page intentionally left blank. 


\subsection{APPLICABLE DOCUMENTS}

The CCS Endpoint Criteria were based on specific requirements contained in Federal regulations, Public Law 101-510, U.S. Department of Energy (DOE) Orders, State Regulations (Washington State Department of Ecology regulations and compliance agreements), and WHC requirements and procedures. The CCS Performance Characteristics were based on WHC design documents, safety analysis, and system performance criteria documents.

\subsection{GOVERNMENT DOCUMENTS}

The following documents of the exact issue shown form a part of this specification to the extent specified herein. In the event of conflict between the documents referenced herein and the contents of this specification, the contents of this specifications shall be considered a superseding requirement.

\subsubsection{Specifications}

WHC, 1991, Workmanship Standards, WHC-CM-8-9, Westinghouse Hanford Company, Richland, Washington.

WHC, 1992a, Type $K$ Thermocouples; Instrument Tree Installations, HS-VP-0029, Rev 0 , Westinghouse Hanford Company, Richland, Washington.

WHC, 1992b, Industrial Safety Manual, WHC-CM-4-3, Westinghouse Hanford Company, Richland, Washington.

WHC, 1992c, Nuclear Criticality Safety Manual, WHC-CM-4-29, Westinghouse Hanford Company, Richland, Washington.

WHC, 1993a, Hanford Solid Waste Acceptance Criteria, WHC-EP-0063-4, Westinghouse Hanford Company, Richland, Washington.

WHC, 1993b, Hazardous Material Packaging and Shipping WHC-CM-2-14, Westinghouse Hanford Company, Richland, Washington.

WHC, 1993C, Training Administration Manual, WHC-CM-2-15, Westinghouse Hanford Company, Richland, Washington.

WHC, 1994a, Waste Storage Tank and Leak Detection Criteria, WHC-SD-WM-TI-357, Rev 1k, Westinghouse Hanford Company, Richland, Washington.

WHC, 1994b, Single-Shell Tank Interim Operational Safety Requirements, WHC-SD-WM-OSR-005, Rev OB, Westinghouse Hanford Company, Richland, Washington.

WHC, 1994c, Tank Farm Stack Sampling System Configuration and Efficiency Study, WHC-SDWM-ES-291, Rev 1, Westinghouse Hanford Company, Richland, Washington. 
WHC, 1995a, Health Physics Procedures, WHC-IP-0718, Westinghouse Hanford Company, Richland, Washington.

WHC, 1995b, Operating Specifications for Single-Shell Waste Storage Tanks, WHC-OSD-T-151-00013, Rev D-9, Westinghouse Hanford Company, Richland, Washington.

WHC, 1995c, Waste Tank Summany Report for Month Ending December 31, 1995, Westinghouse Hanford Company, Richland, Washington.

WHC, 1995d, Tank Waste Remediation System (TWRS) Abandoned Equipment Storage/Disposal Plan, WHC-SD-WM-PLN-098, Rev 0, Westinghouse Hanford Company, Richland, Washington.

WHC, 1995e, Tank Waste Remediation System (TWRS) Administration Manual, WHC-IP-0842, Volume IV, Westinghouse Hanford Company, Richland, Washington.

WHC, 1995f, TMACS Functional Requirements, WHC-SD-WM-SFR-006, Rev 0, Westinghouse Hanford Company, Richland, Washington.

WHC, 1995g, Technical Bases for Leak Detection Surveillance of Waste Storage Tanks, WHC-SD-WM-T1-573, Rev 1, Westinghouse Hanford Company, Richland, Washington.

WHC, 1995h, Operating Specifications for Tank Farm Leak Detection and Single-Shell Tank Intrusion Detection, WHC-OSD-T-151-00031, Rev B-1, Westinghouse Hanford Company, Richland, Washington.

WHC, 1995i, Facility Effluent Monitoring Plan for Tank Farm for the Tank Farm Facility, WHC-EP-0479-1, Westinghouse Hanford Company, Richland, Washington.

WHC, 1996a, Environmental Compliance Manual, WHC-CM-7-5, Westinghouse Hanford Company, Richland, Washington.

WHC, 1996d, Operating Specifications for Watch-List Tanks, WHC-OSD-T-151-00030, Rev B-16, Section 30.2, Westinghouse Hanford Company, Richland, Washington.

WHC, 1996e, Tank Farm Health and Safety Plan, WHC-SD-WM-HSP-002, Rev 2D, Westinghouse Hanford Company, Richland, Washington.

WHC, 1996f, Tank Fams Dangenous Waste Training Plan, WHC-SD-WM-TR-026, Rev 4, Westinghouse Hanford Company, Richland, Washington.

\subsubsection{Standards}

ANSI, 1995, American National Standard for Voltage Ratings for Electrical Power Systems and Equipment, American National Standards Institute, ANSI C84.1, New York, New York.

CFR, 1993, Occupational Radiation Protection, 10 CFR 835.603, Code of Federal Regulations, Office of the Federal Register, National Archives and Records Administration, Washington, DC. 
CFR, 1994a, Occupational Safety and Health Administration, 29 CFR 1910, Code of Federal Regulations, Office of the Federal Register, National Archives and Records Administration, Washington, DC.

CFR, 1994b, Test Methods and Procedures, 40 CFR 61.93, Code of Federal Regulations, Office of the Federal Register, National Archives and Records Administration, Washington, DC.

CFR, 1994c, Nuclear Safety Management, 10 CFR 830, Code of Federal Regulations, Office of the Federal Register, National Archives and Records Administration, Washington, DC.

CFR, 1994d, National Emission Standards for Hazardous Air Pollutants, 40 CFR 61, Subpart H, Emission Standards for Emission of Radjonuclides Other Than Radon From Department of Energy Facilities, Office of the Federal Register, National Archives and Records Administration, Washington, DC.

CFR, 1994e, Quality Assurance Requirements, 10 CFR 830.120, Code of Federal Regulations, Office of the Federal Register, National Archives and Records Administration, Washington, DC.

DOE, 1989, General Design Criteria, DOE Order 6430.1A, U.S. Department of Energy, Washington DC.

DOE, 1992a, Nuclear Safety Analysis Reports, DOE Order 5480.23, U.S. Department of Energy, Washington DC.

DOE, 1992b, Conduct of Operations, DOE Order 5480.19, U.S. Department of Energy, Washington DC.

DOE, 1994, Personnel Selection, Qualification, Training, and Safety Requirements at DOE Reactor and Non-Reactor Facilities, DOE Order 5480.20A, U.S. Department of Energy, Washington DC.

DOE-RL, 1993, Hanford Plant Standard, Standard Arch-Civil Design Criteria, Design Loads for Facilities, HPS-SDC-4.1 , U.S. Department of Energy, Richland Operations Office, Richland, Washington.

DOE-RL, 1995, Letter, J. E. Rasmussen, DOE-RL, to M. Gearheard and M. Wilson, Ecology, Management of Contaminated Equipment at the Hanfond Site, 95-PCA-337, June 9, 1995.

MIL-STD, Human Engineering Design Criteria for Military System Equipment and Facilities, MIL-STD-1472D.

PNNL, 1994, Hanford Site Radiological Control Manual, HSRCM-1, Rev 2, U.S. Department of Energy's Pacific Northwest National Laboratory, operated by Battelle Memorial Institute, Richland, Washington.

U.S. Congress, 1990, Safety Measures for Waste Tanks at Hanford Nuclear Reservation, Section 3137 of National Defense Authorization Act for Fiscal Year 1991, Public Law 101. 510, United States Congress, Washington, DC.

WAC, 1995a, Washington Administrative Code, Dangerous Waste Regulations, Chapter 173-303, State of Washington, Olympia, Washington. 
WAC, 1995b, Washington Administrative Code, Radiation Protection-Air Emissions Chapter 246-247, State of Washington, Olympia, Washington.

WAC, 1995c, Washington Administrative Code, General Regulations for Air Pollution, Chapter 173-400, State of Washington, Olympia, Washington.

WAC, 1995d, Washington Administrative Code, Operating Permit Regulation, Chapter 173-401, State of Washington, Olympia, Washington.

WAC, 1995e, Washington Administrative Code, Control for New Sources of Toxic Air Pollutants, Chapter 173-460, State of Washington, Olympia, Washington.

WAC, 1995f, Washington Administrative Code, Ambient Air Quality Standards and Emission Limits for Radionuclides, Chapter 173-480, State of Washington, Olympia, Washington.

\subsubsection{Drawings}

Not applicable.

\subsubsection{Other Publications}

WHC, 1995k, Tank Waste Remediation System Mission Analysis, WHC-SD-WM-MAR-008, Rev 0 , Westinghouse Hanford Company, Richland, Washington.

WHC, 1995I, Tank Farm Instrumentation Upgrade Plan, WHC-SD-WM-WP-132, Rev 5, Westinghouse Hanford Company.

WHC, 1996b, Mission Analysis Report for Controlled, Clean, and Stable Single Shell Tank Farm, WHC-SD-WM-MAR-010, Rev 0, Westinghouse Hanford Company, Richland, Washington.

Copies of specifications, standards, drawings, and publications required by suppliers in connection with specified procurement functions should be obtained from the contracting agency or as directed by the contracting agent.

\subsection{NON-GOVERNMENT DOCUMENTS}

Not applicable. 


\subsection{PROJECT FUNCTIONS AND REQUIREMENTS}

\subsection{DEFINITION}

The primary CCS project function is to transition the SST Farms to a safe, limited-surveillance and maintenance mode. Transition to this mode will require upgrading system hardware and infrastructure, and removing surface contaminants and pumpable liquid wastes from the SST Farms. The resultant condition of these farms will be a CCS end state.

The CCS Mission Goals and Objectives were developed to meet the TWRS Mission Goal to "Operate and maintain facilities to provide continued safe and environmentally sound storage." The CCS Mission Goals provide specific goals that support the TWRS Mission Goal for safe and environmentally sound storage.

The CCS Mission Goals and Objectives support the TWRS Mission Goals identified in the Tank Waste Remediation System Mission Analysis (WHC 1995k). The CCS function elements and endpoint criteria (performance requirements) provide the functional hierarchy and performance characteristics for meeting the CCS Mission Goals and Objectives.

The SSTs, Inactive Miscellaneous Underground Storage Tanks (IMUSTs), equipment, and structures within the tank farm physical boundaries (fences) are considered to be subject to CCS criteria. Because the CCS project is applicable only to inactive waste receipt facilities, active Double-Contained Receiver Tanks (DCRTs), and waste transfer systems are not subject to CCS criteria. In addition, IMUSTs and Tank Farm facilities located adjacent to, but outside of, SST Farm perimeters, are not required to meet CCS specifications.

\subsection{CHARACTERISTICS}

The CCS project is an integral part of the Systems Engineering (SE) management approach for the TWRS program. The CCS Mission Goals and Objectives led to the project characteristics identified in this section. The CCS performance characteristics are documented in Section 3.2.1. The functional hierarchy for CCS is presented in a block diagram in Figure 3-1.

"Manage Tank Waste" is a level 3 function in the TWRS SE database. This major function has four lower level functions, two of which are applicable to CCS. These two level-four functions are "Store Managed Tank Waste" and "Transfer Managed Tank Waste."

The "Store Managed Tank Waste" function has five lower level functions (level 5), four of which relate to CCS:

- $\quad$ Store SST Waste;

- Store Miscellaneous Underground Storage Tank Waste;

- Manage System and Data Information; and

- Manage SST Farm Boundary. 
WHC-SD-WM-DRD-009, Rev 1

This page intentionally left blank. 

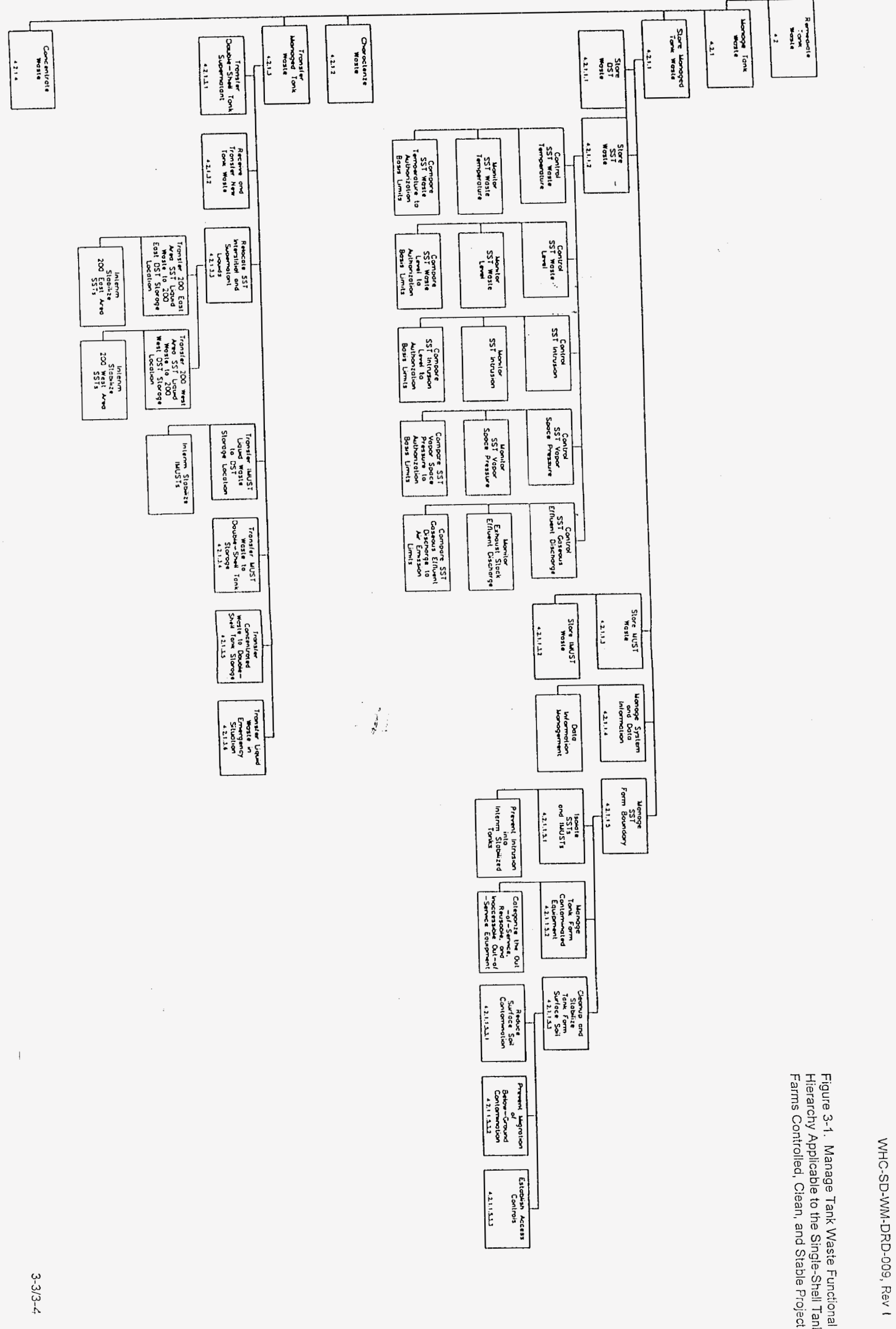


\section{WHC-SD-WM-DRD-009, Rev 1}

The "Transfer Managed Tank Waste" function has seven, lower level functions (level 5), two of which relate to $\mathrm{CCS}$. These two functions are:

- Relocate SST Interstitial and Supematant Liquid; and

- Transfer IMUST Liquid Waste to Double-Shell Tank (DST) Storage.

\subsubsection{Performance Characteristics}

3.2.1.1 Store Single-Shell Tank Waste. The current SST waste inventory shall be minimized by pumping out drainable interstitial liquid (DIL) and supermatant to the extent that is technically practical. The remaining inventory shall be stored. The subfunctions of Store SST Waste, which are applicable to CCS, include Control SST Waste Temperature, Control SST Waste Level, Control SST Intrusion, Control SST Vapor-Space Pressure, and Control SST Gaseous Effluent Discharge.

3.2.1.1.1 Control Single-Shell Tank Waste Temperature. The SST waste temperature shall be controlled to prevent unacceptable chemical reactions (e.g., flammable gas bum or ferrocyanide reactions), excessive stresses to the primary tank, and structural degradation of the concrete shell. The waste temperature shall be controlled by monitoring the temperature, comparing the temperature to authorization basis limits, and maintaining the temperature within established limits.

3.2.1.1.1.1 Monitor Single-Shell Tank Waste Temperature. This subfunction is applicable to High-Heat and Watch-List SSTs. The waste and vapor-space temperature of High-Heat and Watch-List SSTs shall be monitored. Tank temperature is monitored to ensure that the temperature is maintained below the Safety Limits and the Limiting Conditions for Operations (LCO) identified in the Single-Shell Tank Interim Operational Safety Requirements (IOSR) (WHC 1994b). Monitoring includes obtaining, transmitting, receiving, recording, displaying, and reporting the appropriate temperature data.

3.2.1.1.1.1.1 Single-Shell Tank Waste Temperature Measurement Range. Temperature sensing devices shall be installed in all High-Heat and Watch-List SSTs. There shall be two temperature sensing devices operable for each tank, one in the vapor space and one in the waste [see Tank Farm instrumentation Upgrade Plan, WHC-SD-WM-WP-132 (WHC 1995I)]. The temperature sensing devices shall be capable of monitoring temperature over a range of $50^{\circ} \mathrm{F}$ to $400^{\circ} \mathrm{F}$ [Refer to Waste Storage Tank and Leak Detection Criteria, WHC-SD-WM-TI-357 (WHC 1994a)]. Each temperature sensing device shall measure the actual temperature to within $\pm 4{ }^{\circ} \mathrm{F}$ [Refer 10 Type ' $K$ ' Thermocouples; Instrument Tree Installation Specification (WHC 1992a)].

The specifications (performance requirements) for temperature monitoring are based on the design requirements for the existing installed instrumentation (e.g., Type $K$ Thermocouples); the TWRS Authorization Basis (i.e., the Single-Shell Tank Interim Operational Safety Requirements (WHC 1994b); Operating Specifications for Watch-List Tanks (WHC 1996d); and associated subtier specifications/criteria referenced by the TWRS Authorization Basis.

3.2.1.1.1.2 Compare Single-Shell Tank Waste Temperature to Authorization Basis Limits. The Instrument and Control system shall compare data received from the Monitor SST Waste Temperature function to authorization basis limits, and initiate the applicable remote alarm if the limits are exceeded.

3.2.1.1.1.2.1 Single-Shell Tank Waste Temperature Alarm Limits. Instrument strings associated with the temperature monitoring sensors in High-Heat and Watch-List SSTs shall be tied into the Temperature Monitoring and Control System (TMACS) or an equivalent central data acquisition 


\section{WHC-SD-WM-DRD-009, Rev 1}

station. The temperature monitoring systems shall provide monitoring and alarm functions via TMACS or an equivalent system.

The TMACS shall have the capability for providing high-temperature alarms that are adjustable over a range of $50^{\circ}$ to $350^{\circ} \mathrm{F}$. The maximum high-temperature alarm setting shall be as follows:

- At $350^{\circ} \mathrm{F}$ (Safety Limit alam) and $300^{\circ} \mathrm{F}$ (LCO Limit alarm) for High-Heat Tanks [Refer to Operating Specifications for Single-Shell Waste Storage Tanks, OSD-T151-0013 (WHC 1995b), and Single-Shell Tank Interim Operational Safety Requirements, WHC-SD-WM-OSR-005 (WHC 1994b)];

- At $18^{\circ} \mathrm{F}$ above the established baseline temperature for Watch-List Tanks containing ferrocyanide [ Refer to Waste Storage Tank and Leak Detection Criteria, WHC-SD-WM-TI-357 (WHC 1994a)]; and

- At $35^{\circ} \mathrm{F}$ above the established baseline temperature for Watch-List Tanks containing Hydrogen [Refer to Waste Storage Tank and Leak Detection Criteria, WHC-SD-WM-TI-357 (WHC 1994a)].

3.2.1.1.2 Control Single-Shell Tank Waste Level. The SST waste level shall be controlled to prevent tank overfiling, provide waste accountability, and detect primary tank leaks. The waste level shall be controlled by monitoring the level, comparing the level to authorization basis limits, and maintaining the waste level within authorization limits.

3.2.1.1.2.1 Monitor Single-Shell Tank Waste Level. The SST waste level shall be monitored to ensure that the level is maintained below the Safety Limits and the LCO in the Single-Shell Tank Interim Operational Safety Requirements (WHC 1994b). Monitoring includes obtaining, transmitting, receiving, recording, and displaying the level data.

3.2.1.1.2.1.1 Single-Shell Tank Waste-Level Measurement Range. Waste-level measuring devices shall be installed in all SSTs. The waste-level measuring system shall provide level measurements for a minimum range from -5 in. to 600 in. The measurement devices shall have an accuracy of $\pm 0.5 \mathrm{in}$. for tanks with liquid and floating solid surfaces, and $\pm 3.0 \mathrm{in}$. for tanks with solid conductive surfaces [Refer to Technical Bases for Leak Detection Surveillance of Waste Storage Tanks (WHC 1995g)].

3.2.1.1.2.2 Compare Single-Shell Tank Waste Level to Authorization Basis Limits. The SST waste level monitoring system shall provide data to the TMACS or an equivalent system capable of alarming at, or below, the authorization basis limits.

3.2.1.1.2.2.1 Single-Shell Tank Waste Level Alarm Limits. The surface-level monitoring system shall be tied into the TMACS or an equivalent central data acquisition station. The Safety Limits [Refer to Single-Shell Tank Interim Operational Safety Requirements, WHC-SD-WM-OSR-005, Safety Criteria 2.1 (WHC 1994b)] require that the waste level be controlled such that it is below prescribed limits. Therefore, alarms are required to alert Operations personnel before the waste level reaches the prescribed limits. Alarms shall be set at, or below, the following levels:

- For SSTs in A, AX, and SX Tank Farms, $\leq 365$ in.;

- For SSTs in BY, S, TX, and TY Tank Farms, s 281 in.;

- For SSTs in BX Tank Farm, $\leq 189$ in.;

- For SSTs (except for 200 series tanks) in B, C, T, and U Tank Farms, s 189 in.; and

- For 200 series SSTs in B, C, T, and U Tank Farms, $\leq 285$ in. 
The operating specification limit for waste level [Refer to Operating Specifications for Single-Shell Waste Storage Tanks, WHC-OSD-T-151-00013, Section 13.2.1.B (WHC 1995b) requires that the waste levels be monitored at, or below, the prescribed limits. Therefore, high-level alarms are required to alert Operations personnel before the waste level reaches the prescribed limits. High-level alarms shall be set at, or below, the following levels:

- For SSTs in A, AX, and SX Tank Farms, $\leq 360$ in.;

- For 200 series SSTs in B, C, T, and U Tank Farms, $\leq 280$ in.;

- For 100 series SSTs in B, BX, C, T, and U Tank Farms, $\leq 185$ in.; and

- For SSTs in BY, S, TX, and TY Tank Farms, $\leq 275$ in.

3.2.1.1.3 Control Single-Shell Tank Intrusion. Intrusion into SSTs shall be controlled to prevent tank overfilling, provide accountability of the waste. Intrusion is controlled by monitoring for intrusion, comparing the intrusion rate to authorization basis limits, and maintaining the intrusion rate within authorization limits.

3.2.1.1.3.1 Monitor Single-Shell Tanks Intrusion. The SST level shall be monitored to obtain data that will be used to indicate if an intrusion (in-leakage) has occurred in a previously stabilized and isolated tank. Monitoring includes obtaining, transmitting, receiving, recording, and displaying tank level data.

3.2.1.1.3.1.1 Single-Shell Tank intrusion Measurement Range. Tank level measuring devices shall be installed in all SSTs. Tank level measurements shall be provided for a minimum range of $-5 \mathrm{in}$. to $600 \mathrm{in}$. The measurement devices shall have an accuracy of $\pm 0.5 \mathrm{in}$. for tanks with liquid and floating solid surfaces, and \pm 3.0 in. for tanks with solid conductive surfaces [Refer to Technical Bases for Leak Detection Surveillance of Waste Storage Tanks (WHC 1995g)].

3.2.1.1.3.2 Compare Single-Shell Tank Level to Authorization Basis Limits. The TMACS or an equivalent remote data acquisition system shall compare the data received from the Monitor Single-Shell Tanks Intrusion function to authorization basis limits, and initiate the applicable remote alarm if the limits are exceeded.

3.2.1.1.3.2.1 Single-Shell Tank Intrusion Level Alarm Limits. The surface level/intrusion monitoring system shall be tied into TMACS or an equivalent central data acquisition station.

Alarm setpoints shall be adjustable from 0 in. to 365 in. Alarm settings for Intrusion detection for different tank surfaces are specified in Operating Specifications for Tank Farm Leak Detection and Single-Shell Tank Intrusion Detection (WHC 1995h); and Technical Bases for Leak Detection Surveillance of Waste Storage Tanks (WHC 1995g). These setpoints shall be as follows:
a. Liquid Surface Tanks-A verified reading $+0.5 \mathrm{in}$. from the reference baseline, or +1.0 in. from the reference baseline for tanks exhibiting significant seasonal variations;
b. Partial Liquid Surface-A verified reading +1.0 in. from the reference baseline; and
c. Conductive Solid Surface-A verified reading $+3.0 \mathrm{in}$. from the reference baseline.

The Tank Waste Remediation System Administration Manual, WHC-IP-0842, Volume IV, Section 4.11 (WHC 1995e), provides the general requirements for establishing SST surface-level and temperature baselines. 
3.2.1.1.4 Control Single-Shell Tank Vapor-Space Pressure. The SST vapor-space pressure shall be controlled to prevent over-pressurization and under-pressurization of the tank, and to protect the tank against structural damage. The vapor-space pressure shall be controlled by monitoring the vapor-space pressure, comparing the vapor-space pressure to authorization basis limits, and maintaining the vapor-space pressure within the authorization limits.

3.2.1.1.4.1 Monitor Single-Shell Tank Vapor-Space Pressure. The vapor-space pressure shall be monitored in actively ventilated SSTs. Vapor-space pressure is monitored to ensure that pressure is maintained within the range specified in appropriate Safety Limits and LCO in the Single-Shell Tank Interim Operational Safety Requirements (WHC 1994b). Monitoring includes obtaining, transmitting, receiving, recording, and displaying the data.

3.2.1.1.4.1.1 Single-Shell Tank Vapor-Space Pressure Measurement Range. Tank pressure monitoring systems shall be instalied and operable for actively ventilated SSTs. The pressure monitoring system shall provide SST vapor-space pressure over a minimum range from - 15- to 0 -in. water gauge, with a resolution of 0.1 -in. water gauge, and an accuracy of \pm 0.1 -in. water gauge.

3.2.1.1.4.2 Compare Single-Shell Tank Vapor-Space Pressure To Authorization Basis Limits. The Instrument and Control system shall compare data received from the Monitor Vapor Space Pressure function to authorization basis limits, and initiate the applicable remote alarm if limits are exceeded.

3.2.1.1.4.2.1 Single-Shell Tank Vapor-Space Pressure Alarm Limits. The instrument strings associated with the pressure monitoring sensors identified for actively ventilated tanks shall be tied into TMACS or an equivalent central data acquisition station. The pressure monitoring systems required shall provide monitoring and alarm functions via TMACS or an equivalent system. The LCO alarm settings for the tank vapor-space pressure, relative to atmosphere [Refer to Single-Shell Tank Interim Operational Safety Requirements, Section 3.3 (WHC 1994b)], shall be as follows:

- For tanks with 210 in. of waste, the tank pressure alarm setting shall be $\geq-9.5$-in. water gauge;

- For tanks with $<10$ in., but $>4.5$ in. of waste, the tank pressure alarm setting shall be $z$ the negative of the waste height minus 0.5 -in. water gauge; and

- For tanks with $<4.5$ in. of waste, the tank pressure alarm setting shall be $z-4$-in. water gauge.

The Safety Limit alarm settings for the tank vapor-space pressure, relative to atmosphere [Single-Shell Tank Interim Operational Safety Requirements, Section 2.3 (WHC 1994b)], shall be as follows:

- For tanks with $\geq 15$ in. of waste, the tank pressure alarm setting shall be $z-15$-in. water gauge;

- For tanks with $<15$ in., but $\geq 6$ in. of waste, the tank pressure alarm setting shall be $z$ the negative of the waste height in inches water gauge; and

- For tanks with $<6$ in. of waste, the tank pressure alarm setting shall be $>-6$-in. water gauge. 
3.2.1.1.5 Control Single-Shell Tank Gaseous Effluent Discharge. The SST radioactive gaseous/particulate effluents shall be controlled in accordance with applicable laws and regulations per Radiation Protection-Air Emissions (WAC 1995b); General Regulations for Air Pollution (WAC 1995C); Ambient Air Quality Standards and Emission Limits for Radionuclides (WAC 1995f).

3.2.1.1.5.1 Monitor Single-Shell Tank Gaseous Effluent Discharge. The SST radioactive gaseous/particulate effluents shall be measured in accordance with applicable laws and regulations per National Emission Standards for Hazardous Air Pollutants, 40 CFR 61, Subpart H (CFR 1994d). Effluent measuring includes record sampling, monitoring, alarm, and reporting capabilities.

3.2.1.1.5.1.1 Single-Shell Tank Ventilation Exhaust-Stack Radioactivity Measurement Range. The Exhaust-stack Radiation Measurement system shall be installed and operable on actively ventilated SSTs.

Continuous measurement and alarm capability shall be provided for Exhaust-Stack Radiation in actively ventilated tanks, if projected offsite effective dose-rate equivalent is greater than 0.1 mrem/year [Refer to Section 2.5.3.2 of the Environment Compliance Manual, WHC-CM-7-5 (WHC 1996a)].

Continuous Air Monitors (CAMs) shall be capable of measuring one Derived Air Concentration (DAC) when averaged over 8 hrs [Refer to Health Physics Procedures, Section 4.2, Continuous Air Monitoring, WHC-IP-0718 (Appendix I) (WHC 1995a); and to the Facility Effluent Monitoring Plan for Tank Farm Facility (WHC 1995i)].

The "Methods and Standards" in 40 CFR 60-93 (CFR 1994b) identify the design requirements for gaseous effluent monitoring systems. The sampling methods specified are established to ensure that the sampling systems provide an accurate measure of the effluent discharge.

These methods and standards require that the radionuclide sampling system shall be designed to provide representative sampling. Alternate methods, such as those proposed in the Hanford Site Clean Air Act Permit submittal, are allowed if they can be demonstrated to provide an equivalent monitoring capability by performance testing as approved by regulators.

3.2.1.1.5.2 Compare Single-Shell Tank Gaseous Effluent Discharge To Air Emission Limits. The Instrument and Control system shall compare data received from the Effluent Discharge Measuring System to air emission limits, and initiate the applicable remote alarm if the limits are exceeded.

3.2.1.1.5.2.1 Single-Shell Tank Gaseous Effluent Discharge Alarm Limits. The CAMs shall provide an alarm(s) on the TMACS Operator Console, or an equivalent remote monitoring system.

Exhaust-stack radiation monitoring systems shall have the capability to alarm at predefined setpoints [Refer to Environmental Compliance Manual, WHC-CM-7-5 (WHC 1996a)]. Alarm setpoints shall be set to the values specified in the Facility Effluent Monitoring Plan for the Tank Farm Facility (WHC 1995i).

The CAM alarm setpoints are set by Radiological Control Technicians (RCTs) by the procedure specified in Health Physics Procedures, WHC-IP-0718, Appendix I, Section 4.2 (WHC 1995a). 
3.2.1.2 Manage System Data /Information. Information generated by the Store Managed Tank Waste function shall be managed. Information management shall include remote monitoring sensors, alarms, and trend data by obtaining, analyzing, processing, storing, and archiving system information. This includes providing user interfaces, and exporting data to other information management systems.

3.2.1.2.1 Data Information Management. The data information management subfunction shall include "Obtaining Data, Analyzing, Processing, Storing, and Archiving System Information." Performance requirements for obtaining system data have been discussed in Section 3.2.1.1.

3.2.1.2.2 Performance Requirements. The system Performance Requirements for analyzing, processing, storing, and displaying data were obtained from the TMACS Functional Requirements (WHC 1995f). The performance requirements are as follows:

- Logging (disk)

- $\quad 2,500$ points at 30 -min intervals,

- 200 points at 10-sec intervals, and

- $\quad 1,000$ points at 5-min intervals;

- Operator interface

- At a minimum, two active operator interfaces,

- Display call-up in 3 sec or less, and

- $\quad$ Dynamic update of 20 variables per display every $5 \mathrm{sec}$;

- Polling and Alarm checking

- $\quad 200$ points at $10-\sec$ intervals,

- $\quad 1,000$ points at $1-$ min intervals, and

- $\quad 3,800$ points at $10-$ min intervals; and

- Trends

- 20 real-time trend displays, each with three variables, and

- $\quad$ All variables trending at $1-$ min periods.

3.2.1.3 Manage Single-Shell Tank Farm Boundary. The function for "Manage SST Farm Boundary" includes the following subfunctions:

- Isolate SSTs and IMUSTs;

- Manage Tank Farm Contaminated Equipment; and

- Cleanup and stabilize Tank Farm Surface Soil.

3.2.1.3.1 Isolate Single-Shell Tanks and Inactive Miscellaneous Underground Storage Tanks. All SST and IMUST systems/components shall be sealed to prevent tank intrusion. 


\section{WHC-SD-WM-DRD-009, Rev 1}

3.2.1.3.1.1 Prevent Intrusion Into Interim-Stabilized Tanks. Tanks that have been documented to be interim isolated and intrusion prevented require no additional intrusion prevention. However, intrusion prevention material that has been identified as damaged must be repaired. Intrusion Prevention includes disconnecting and blanking or capping pipelines from tank systems, and disconnecting, capping, and sealing applicable risers and pipelines per the following criteria listed in the Tank Waste Remediation System Administration Manual, WHC-IP-0842, Volume IV, Section 4.2, Revision Oa (WHC 1995e):

- $\quad$ Risers terminating above-grade or less than $3 \mathrm{ft}$ below-grade shall be sealed to withstand a pressure of 12 inches of water ( $0.43 \mathrm{psig}$ ); and

- Risers terminating in a confined area (pits, cells, vaults, etc.) need not be sealed if the confinement cover is sealed against a minimum pressure of 12 inches of water $(0.43 \mathrm{psig})$, and all pipelines connected to the confinement meet the criteria noted below for pipelines

- Seal pipelines entering any tank or above-grade structures connected to that tank with closure devices, which are designed to prevent unauthorized removal, capable of sealing against a pressure of 12 inches of water $(0.43 \mathrm{psig})$.

3.2.1.3.2 Manage Tank Farm Contaminated Equipment. The SST Farms contain equipment that has been contaminated with tank waste and/or radioactive materiais. This equipment must be characterized, inventoried, and dispositioned as reusable equipment, or waste.

3.2.1.3.2. 1 Categorize the Out-of-Service, Reusable, and Inaccessible Out-of-Service Equipment. The categorized equipment shall be dispositioned per the Management of Contaminated Equipment at the Hanford Site (DOE-RL 1995); and the TWRS Abandoned Equipment Storage/Disposal Plan (WHC 1995d). Above-ground, out-of-service contaminated equipment that is not reusable and is inaccessible or difficult to remove (based on the risk and cost involved) shall be sealed to prevent contamination spread, in accordance with Section 3.2.1.3.1.1; for example, vertical storage wells and non-functional vadose monitoring wells. Vertical storage wells shall be filled with gravel; and non-functional vadose wells shall be decommissioned by perforating, filling with grout and cutoff below grade. The well pipe is perforated to allow grout extrusion through the well wall and into any voids that might exist around the outside of the well pipe. This will minimize contamination spread caused by liquids flowing around the outside of the well.

All above-ground out-of-service contaminated equipment and small lightly constructed (e.g., sheetmetal) buildings that are not reusable shall be inventoried and dispositioned. Dispositioning in most cases will require characterizing the waste constituents, removing and packaging the equipment and structures as waste, and designating the waste containers in accordance with WAC 173-303 (WAC 1995a).

Large and/or stout (e.g., concrete) out-of-service structures requiring significant resources for disposal may be stabilized in place. Stabilized structures with radioactively contaminated surfaces (as a goal) shall be decontaminated to levels consistent with Environmental Restoration guidelines. Surfaces or areas, that can potentially recontaminate the farms, exceeding the Table 2-2 values of the Hanford Site Radiological Control Manual, HSRCM-1 (PNNL 1994) shall be sealed with a fixative coating. Fixative coating application and marking shall be in accordance with Article 222 of the Hanford Site Radiological Control Manual, HSRCM-1 (PNNL 1994).

Reusable contaminated equipment shall be managed in accordance with as low as reasonably achievable (ALARA) guidelines and the WAC 173-303 (WAC 1995a) requirements relevant to 
storage of dangerous wastes (where appropriate). This will provide Environmentally Compliant Storage for Reusable Equipment.

3.2.1.3.3 Cleanup and Stabilize Tank Farm Surface Soil. The surface soil in the SST Farms shall be sufficiently free of radioactive contamination, and stabilized. Cleanup and stabilization of surface soil shall reduce the risk of personnel exposure to loose contamination to ALARA standards. Cleanup and stabilization of tank farm surface soil includes reducing surface soil contamination, preventing of below-grade contamination migration, and establishing tank farm access controls.

3.2.1.3.3.1 Reduce Surface Soil Contamination and Radiation Levels in the Single-Shell Tank Farms. Surface contamination levels shall be reduced to less than 5,000 disintegration per minute (DPM) (Beta/Gamma) per $100 \mathrm{~cm}^{2}$ direct (fixed and removable), and less than 1,000 DPM (Beta/Gamma) per $100 \mathrm{~cm}^{2}$ removable, per Table 2-2 of the Hanford Site Radiological Control Manual, HSRCM-1 (PNNL 1994).

Radiation levels shall be less than $100 \mathrm{mrem} / \mathrm{hr}$ at a distance of $30 \mathrm{~cm}$ or 12 in. from the radiation source, as required by Table 2-3 of the Hanford Site Radiological Control Manual, HSRCM-1 (PNNL 1994).

3.2.1.3.3.2 Prevent Migration of Below-Grade Contamination. Surface soil within SST Farms shall be stabilized to prevent below-grade contamination from migrating to the surface. For example, fixant or noncontaminated compactable soil may be used to stabilize the contamination. Verification of adequate stabilization shall be through normal periodic surveillances.

3.2.1.3.3.3 Establish Access Controls. Access into the SST Farms shall be restricted, by establishing administrative and physical controls, as required by Occupational Radiation Protection, 10 CFR 835.603 (CFR 1993), and Dangerous Waste Regulations, Section 310 WAC 1995a). The controls established will depend on the classification of the tank farm boundary [i.e., Underground Radioactive Material Area (URMA), Radiological Buffer Area (RBA), Radiation Area (RA)].

A grid survey shall be performed for downposting within the farm perimeters per the Health Physics Procedures, Rev 3, Section 3.1.2, Survey Method for Reposting Outdoor Contamination Areas (WHC 1995a).

Each URMA, RBA, or RA access point shall be posted with the applicable sign in accordance with the Hanford Site Radiological Control Manual (PNNL 1994).

3.2.1.4 Relocate Single-Shell Tank Interstitial and Supernatant Liquids. The SST supematant and interstitial liquid shall be recovered and transferred to a designated DST storage location, prior to final processing. The SST liquid wastes are those liquids that can be moved (i.e., pumpable) without any waste conditioning prior to movement. Recovery and transfer of these liquids shall continue until the SSTs are interim stabilized.

3.2.1.4.1 Transfer 200 East Area Single-Shell Tank Liquid Waste to 200 East Area Double-Shell Tank Storage Location. Pumpable liquid waste remaining in the 200 East Area SSTs shall be recovered and transferred to a designated 200 East Area DST until the SSTs are interim stabilized.

3.2.1.4.1.1 The 200 East Area Single-Shell Tank Waste Total Volume. The 200 East Area Transfer System shall be capable of transferring $1.450 \mathrm{Mgal}$ of pumpable liquid waste [see Waste Tank Summary Report for Month Ending December 31, 1995, Table E-3 (WHC 1995c)] 
from the SSTs to Tank 241-AN-101 (for non-complexed waste) and Tank 241-AY-101 (for complexed waste), designated to receive the 200 East Area liquid waste.

3.2.1.4.1.2 Interim Stabilize 200 East Area Single-Shell Tanks. Liquids from non-interimstabilized 200 East Area SSTs shall be pumped and transferred to 200 East Area DSTs. Each tank shall be pumped until the specifications (criteria) provided in the Tank Waste Remediation System Administration Manual, WHC-IP-0842, Volume IV, Section 4.1 (WHC 1995e) have been satisfied.

The final acceptance criteria for SST interim stabilization are as follows:

a. Each tank contains less than 50,000 gal of DIL, based on either a $45 \%$ porosity, or on the porosity determined during actual pumping;

b. Each tank contains less than 5,000 gal of supematant; and

c. The pumping rate has decreased to less than $0.05 \mathrm{gal} / \mathrm{min}$, or inflow in the saltwell screen has decreased to less than $0.05 \mathrm{gal} / \mathrm{min}$, and the tank has less than $50,000 \mathrm{gal}$ of DIL remaining.

3.2.1.4.2 Transfer 200 West Area Single-Shell Tank Liquid Waste to 200 West Area DoubleShell Tank Storage Location. Pumpable liquid waste remaining in the 200 West Area SSTs shall be recovered and transferred to a designated 200 West Area DST, until the SSTs are interim stabilized.

3.2.1.4.2.1 The 200 West Area Single-Shell Tank Waste Total Volume. The 200 West Area Transfer System shall be capable of transferring $3.66 \mathrm{Mgal}$ of pumpable liquid waste [see Waste Tank Summary Report for Month Ending December 31, 1995, Table E-3 (WHC 1995c) from the SSTs to 241-AN-101 (for non-complexed waste) and 241-AY-101 (complexed waste), designated to receive the 200 West Area liquid waste.

3.2.1.4.2.2 Interim Stabilize 200 West Area Single-Shell Tanks. Liquids from non-interimstabilized 200 West Area SSTs shall be pumped and transferred to 200 West Area DSTs. Each tank shall be pumped until the specifications (criteria) provided in the Tank Waste Remediation System Administration Manual, WHC-IP-0842, Volume IV, Section 4.1 (WHC 1995e), have been satisfied. Final acceptance criteria for interim stabilization of SSTs are as follows:

a. Each tank contains less than 50,000 gal of $\mathrm{DIL}$, based on either a $45 \%$ porosity, or on the porosity determined during actual pumping;

b. Each tank contains less than 5,000 gal of supematant; and

c. Pumping rate has decreased to less than $0.05 \mathrm{gal} / \mathrm{min}$, or if inflow in the saltwell screen has decreased to less than $0.05 \mathrm{gal} / \mathrm{min}$, and the tank has less than $50,000 \mathrm{gal}$ of DIL remaining

3-2.1.5 Transfer Inactive Miscellaneous Underground Storage Tank Liquid Waste to a DoubleShell Tank Storage Location. Recover and transfer the pumpable liquid waste remaining in the IMUSTs to designated DST, until the IMUSTs are interim stabilized.

3.2.1.5.1 Interim Stabilize Inactive Miscellaneous Underground Storage Tanks. Liquids from non-interim-stabilized IMUSTs shall be pumped and transferted to DSTs. The waste transfer system shall be capable of transferring 121,772 gal of pumpable liquid waste. Each tank shall be pumped until the specifications (criteria) provided in the Tank Waste Remediation System 
Administration Manual, WHC-IP-0842, Volume IV, Section 4.1 (WHC 1995e), have been satisfied. Final acceptance criteria for interim stabilization of IMUSTs are as follows:

a. Tanks containing low-level radioactive supematant liquid shall be pumped to 400 gal or less ( 4 in. from the bottom of the solids/sludge level); and

b. Tanks containing more than 5,000 gal of highly radioactive supernatant shall be pumped down via overground piping to an underground tank (not SSTs) or receiver vessel, where tank trucks cannot be used without dilution.

\subsubsection{Project Relationships}

This section is not applicable because the relationship between the requirements and subfunctions is obvious.

\subsubsection{Extemal Interface Requirements}

The CCS has several external interfaces with existing systems and several extemal interfaces with ongoing Projects and Programs. Detailed interface descriptions and identification of exact interface points have not been developed because CCS is being performed on a farm-by-farm basis, and the SST Farm physical conditions are vastly different. Interfaces for one particular farm or group of farms may not be appropriate for other farms. For example, identifying the 241A valve box as an interface for interstitial liquid waste transfer is appropriate for 241-A and 241AX Tank Farms; however, it may be inappropriate for 241-B, BX, BY, C, and the 200 West Area SST Farms. Therefore, the interfaces have been identified and described in general terms.

3.2.3.1 Electrical Power Distribution. Electrical power will continue to be required for the SST Farms to operate instrumentation and active ventilation systems (where installed). Upgrading the electrical power distribution system for SSTs is currently anticipated to be within the scope of future projects such as Project W-314. Future projects are anticipated to provide upgraded power systems up to, and through, the $13.8-1480-\mathrm{V}$ transformers, but will not be upgrading anything beyond the side of the transformer.

3.2.3.2 Waste Transfer System. The waste transfer system will interface with the CCS Project during removal of SST and IMUST interstitial and supernatant liquids. The interface point between CCS liquid waste transfer and the waste transfer system depends on the existing physical condition of the transfer piping for each tank. Liquid waste will be transferred from the SSTs and IMUSTs via existing piping, valves, and pits that are in acceptable physical condition. When the transfer system is not in acceptable condition, liquid waste will be transferred to the closest acceptable waste transfer connection via a temporary above-ground transfer line.

3.2.3.3 Solid Waste Disposal. All solid waste generated by the CCS project shall be managed in accordance with RCRA permits, and Federal and State codes and regulations pertaining to waste management. Packaging and transfer of solid waste shall be in accordance with Hazardous Materials Packaging and Shipping, WHC-CM-2-14 (WHC 1993b); Hanford Site Solid Waste Acceptance WHC-EP-0063-4 (WHC 1993a); Environmental Compliance Manual, WHCCM-7-5 (WHC 1996a); and applicable plant operating procedures.

3.2.3.4 Tank Characterization Project. The Tank Characterization Project interfaces with the waste transfer portion of the CCS project. Prior to transferring waste, an analysis must be performed to ensure the SST and IMUST waste is compatible with the waste in the receiving DST. The Characterization Projects function may be required to obtain a waste sample from the source tank (SST or IMUST) and ensures the sample is analyzed. 
3.2.3.5 Tank Monitoring and Control System. The parameters that must be monitored while SSTs are kept in the limited surveillance and maintenance mode, are identified in Section 3.2.1.1. Monitoring of liquid level, temperature, pressure, and ventilation exhaust-stack radiation are considered essential. All monitoring activities will be done via remote terminals.

3.2.3.6 Tank Farm Safety Program (Flammable Gas Watch-List Tanks). An interface will exist between the Tank Farm Safety Program and the CCS Project for Watch-List SSTs. The CCS project will implement the administrative controls established for Watch-List Tanks. There is one such requirement that Watch-List Tanks must be actively ventilated while liquid waste is being pumped and transferred. Additionally, the CCS project may be impacted by future changes to the listing of tanks on the Watch-List, and by changes to the Watch-List administrative controls.

3.2.3.7 Authorization Basis Development Team. The Authorization Basis Development Team is in the process of revising the authorization basis for tank farms. The development team interfaces with the CCS Project in that changes to the authorization basis will impact CCS. Completion of the authorization basis development is expected in Fiscal Year 1996; therefore, interfaces and impacts to the CCS Project cannot be specifically identified at the time this document was written.

\subsubsection{Physical Characteristics}

This section is not applicable to the CCS Project.

\subsubsection{Project Quality Factors}

This section is not applicable to the CCS Project.

\subsubsection{Environmental Conditions}

The systems, subsystems, and components required as part of the CCS Project shall be designed to withstand the environmental conditions specified in this section.

3.2.6.1 Extemal-Weather Related. All systems, subsystems, and components necessary to comply with CCS shall be designed to withstand the natural environments of the Hanford Site; thermal effects of the soil shall also be considered for the system's buried portions. All systems, subsystems, and components must be able to withstand the following environmental conditions:

- Temperatures

- $\quad$ Maximum temperature of $113^{\circ} \mathrm{F}\left(45^{\circ} \mathrm{C}\right)$,

- Minimum temperature of $-24^{\circ} \mathrm{F}\left(-31^{\circ} \mathrm{C}\right)$.

- Rate of Increase at $26^{\circ} \mathrm{F} / 20 \mathrm{~min}$, maximum, and

- Rate of Decrease at $24^{\circ} \mathrm{F} / \mathrm{hr}$, maximum;

- Relative Humidity

- The system shall be designed to operate within a relative humidity range of $5 \%$ to $100 \%$;

- Precipitation

The system shall be designed to withstand an annual mean precipitation of 6.3 in. $(16 \mathrm{~cm})$; and

- Blowing Dust and Smoke

Visibility of $6 \mathrm{mi}(9.65 \mathrm{~km})$ or less, with sky completely obscured

Frequency of $10 \mathrm{times} / \mathrm{yr}$, maximum

Duration of 24 hr/occurrence 
3.2.6.2 Extemal-Natural Induced Forces. All required systems, subsystems, and components that are required for CCS shall comply with the design loads for non-reactor structures specified in HPS-SDC-4.1, Standard Arch-Civil Design Criteria, Design Loads for Facilities,

(DOE-RL 1993), except that the seismic design shall be in accordance with HPS-SDC-4.1.

\subsubsection{Transportability}

This section is not applicable to the CCS Project.

\subsubsection{Flexibility and Expansion}

This section is not applicable to the CCS Project.

\subsubsection{Portability}

This section is not applicable to the CCS Project.

\subsection{DESIGN}

The system shall be designed and constructed in accordance with General Design Criteria, DOE Order 6430.1A, (DOE 1989). The criteria in Sections 99.0, Non-Nuclear Facilities - General, Section 99.17, Radioactive Liquid Waste Facilities, and Section 1300, Special Facilities, are applicable. Additional environmental design requirements are defined in Dangerous Waste Regulations (WAC 1995a); Radiation Protection-Air Emissions (WAC 1995b); General Regulations for Air Pollution (WAC 1995c); Operating Permit Regulation (WAC 1995d); and Control for New Sources of Toxic Air Pollutants (WAC 1995e).

\subsubsection{Materials}

This paragraph is not applicable to this specification. 
WHC-SD-WM-DRD-009, Rev 1

\subsubsection{Electromagnetic Radiation}

This paragraph is not applicable to this specification

\subsubsection{Nameplates and Product Markings}

Specific guidelines for addressing labeling shall be followed and are contained in NUREG 0700, Section 6.6, MIL-STD-1472D, Section 5.5 (MIL-STD); and the DOE Order for Conduct of Operations, DOE 5480.19, Chapter 18, Equipment Piping and Labeling (WHC 1992b).

3.3.3.1 Equipment Labeling. Equipment and components to be operated in the post-CCS mode shall be identified with appropriate labels. The label shall indicate clearly and concisely the component function and purpose.

3.3.3.1.1 Electrical Equipment Labeling. Each disconnecting means required by this subpart for motors and appliances shall be legibly marked to indicate its purpose. Each service, feeder, branch circuit, its disconnecting means or over-current device, equipment supplied, and energy type shall be legibly marked to indicate its purpose, unless located and arranged so the purpose is evident. These markings shall be of sufficient durability to withstand the environment involved.

3.3.3.2 Durability. Permanent labels shall be attached to the specific component or equipment in such a manner that environmental conditions or usage by personnel will not remove nor destroy the label.

3.3.3.3 Legibility. Labeling shall be legible and conform to human visual capabilities and limitation in regard to physical characteristics such as letter and symbol size, contrast, font, simplicity, spacing, and stroke width.

\subsubsection{Workmanship}

The CCS System elements shall conform to the workmanship standards specified in Workmanship Standards, WHC-CM-8-9 (WHC 1991).

\subsubsection{Interchangeability}

This paragraph is not applicable to this specification.

\subsubsection{Safety}

Employee and public safety and health is of paramount importance. Safety will be incorporated into all activities, without exception, to prevent loss and/or damage to human life and the facilities. The safety program will provide an integrated system where employee and public safety and health are considered foremost to the conduct of operations. All activities will be conducted in compliance with applicable DOE and WHC safety requirements. The safety program currently in use at TWRS will be followed. This program has been established to:

- Improve safety knowledge and performance of each employee;

- Reinforce dangerous consequences of unsafe operation; and

- Implement the use of safety skills in the workplace.

The safety program will also emphasize ALARA principles. The primary purpose of ALARA is to reduce radiological exposure to the maximum extent possible, with reasonable financial impact. 
Pre-job safety meetings and safety meetings at regular intervals will be required for all employees. Managers will be strongly encouraged to discuss safety topics in meetings with their employees. These meetings will also be used as a tool to reiterate the safety program importance.

In addition to federal requirements promulgated by DOE, federal regulations conceming Nuclear Safety Management and Occupational Radiation Protection are also applicable to DOE nuclear facilities. The Nuclear Safety Management is covered by 10 CFR 830 (CFR 1994c); whereas the Radiation Protection Standards are addressed in 10 CFR 835 (CFR 1993).

The WHC policy is to ensure that its employees are provided with adequate protection, training, and information about hazardous waste to perform the related operations safely. The requirements for establishing and implementing the Occupational Safety and Health Administration (OSHA) standards for conducting Hazardous Waste Operations and Emergency Response are provided in Occupational Safety and Health Administration, 29 CFR 1910 (CFR 1994a). Those OSHA requirements applicable to the Hanford Site are provided in the industrial Safety Manual, WHC-CM-4-3 (WHC 1992b).

\subsubsection{Human Engineering}

Human Factors criteria documented in the General Design Criteria, DOE 6430.1A, Section 1.30012 (DOE 1989), shall apply to the construction and operation of the CCS hardware.

\subsubsection{Nuclear Control}

The criticality safety program defined in the Nuclear Criticality Safety Manual, WHC-CM-4-29 (WHC 1992c), shall apply to transfer system design and operations involving fissionable material quantities in excess of $3 \%$ of a minimum critical mass.

Process designs shall incorporate sufficient safety factors to require at least two unlikely, independent, and concurrent changes in process conditions before a criticality accident is possible. Protection shall be provided by either of the following

a. The control of two independent process parameters (which is the preferred approach, if practical); or

b. A system of multiple (at least two) controls of a single parameter.

In all cases, no single credible failure shall result in the potential for a criticality accident. The basis for selecting one approach rather than another shall be fully documented.

\subsubsection{System Security}

Existing safeguards and security measures will not be impacted by CCS. No new measures beyond current practices for entry into the 200 East and West Areas will be required for the SST Farms. Physical controls for high-and very high-radiation zones shall comply with the Hanford Site Radiological Control Manual, HSRCM-1, Chapter 3, Appendix 3B (PNNL. 1994).

\subsubsection{Government-Furnished Property Usage}

This paragraph is not applicable to this specification. 
WHC-SD-WM-DRD-009, Rev 1

\subsection{INFORMATION}

This section is not applicable to CCS.

\subsection{LOGISTICS}

\subsubsection{Maintenance}

Remote, limited, or contact maintenance and operation shall be in accordance with the following radiation contact exposure threshold values.

3.5.1.1 Fully-Remote Maintenance and Operation. This section is not applicable to the CCS Project.

3.5.1.2 Limited-Contact Maintenance and Operation. Each system or system portion with radiation levels $\geq 50 \mathrm{mrem} / \mathrm{hr}$ shall be designed for limited-contact maintenance and operation.

3.5.1.3 Full-Contact Maintenance and Operation. This section is not applicable to the CCS project.

\subsubsection{Waste Handling, Storage, and Disposal}

Solid waste handling, storage, and disposal shall be performed in accordance with Hanford Solid Waste Acceptance Criteria, WHC-EP-0063-4 (WHC 1993a); Hazardous Material Packaging and Shipping, WHC-CM-2-14 (WHC 1993b); Dangerous Waste Regulations 173-303 (WAC 1995a); and applicable Plant Operating Procedures.

\subsubsection{Transportation of Hazardous Materials}

Waste that is designated as "dangerous waste" in accordance with the Dangerous Waste Regulations, WAC 173-303 (WAC 1995a), shall be handled, packaged, marked, and transported in accordance with Dangerous Waste Regulations, WAC 173-303 (WAC 1995a); Hazardous Material Packaging and Shipping, WHC-CM-2-14 (WHC 1993b); and appropriate Plant Operating Procedures.

\subsubsection{Supply/Support}

The system design shall, to the greatest extent practicable, use readily available parts and components.

3.5.4.1 Electrical Equipment Supply. Preferred standard voltages in conformance with the American National Standard for Voltage Ratings for Electrical Power Systems and Equipment, ANSI C84.1 (ANSI 1995), shall be used, with a single-voltage level characteristic in any classification, to minimize stocks of spare equipment and to standardize operating and maintenance practices and procedures.

\subsection{PERSONNEL AND TRAINING}

Qualified personnel with proper training are essential to operate any facility, and TWRS is no exception. The Personnel Selection, Qualification, Training, and Safety Requirements at DOE 
Reactor and Non-Reactor Facilities, DOE Order 5480.20A (DOE 1994), describes the selection, qualification, training, and staffing requirements for personnel to operate any DOE-owned nuclear facility. In addition, the Training Administration Manual, WHC-CM-2-15 (WHC 1993c), provides an overview of the training activities required for working at the Hanford Site. Specific training requirements for work in the Tank Farms are provided in the Tank Waste Remediation System Administration Manual, WHC-IP-0842 (WHC 1995e); Tank Farms Dangerous Waste Training Plan, WHC-SD-WM-TR-026 (WHC 1996f); Environmental Compliance Manual, WHC-CM-7-5 (WHC 1996a); and Tank Farm Health and Safety Plan, WHC-SD-WM-HSP-002 (WHC 1996e). Personnel selection and training will be in accordance with the documents referenced in this section, and Dangerous Waste Regulations (WHC 1995a).

\subsection{CHARACTERIZATION OF SUBORDINATE ELEMENTS}

This section is not applicable to the CCS Project.

\subsection{PRECEDENCE}

The Design Requirements Document (ORD) provides SE specifications for the CCS Project. The TWRS Systems Engineering requirements database (RDD 100) provides hierarchial relationships of the precedence of requirements contained herein. Those requirements that are closest to "imposed" requirements in the hierarchy (e.g., CFRs, DOE Orders, etc.) shall carry precedence over those requirements several layers removed from the imposed requirement.

\subsection{QUALIFICATION}

This section is not applicable to the CCS Project.

\subsection{STANDARD SAMPLE}

This section is not applicable to the CCS Project.

\subsection{REPRODUCTION SAMPLE}

This section is not applicable to the CCS Project. 
WHC-SD-WM-DRD-009, Rev 1

This page intentionally left blank. 


\subsection{QUALITY ASSURANCE PROVISIONS}

The work to be accomplished, as described in this DRD, is govemed, for Quality Assurance purposes, by Quality Assurance Requirements, 10 CFR 830.120 (WHC 1994e), which establishes the QA program requirements used for nonreactor nuclear-related work.

The quality assurance program that addresses the requirements of Quality Assurance Requirements, 10 CFR 830.120 (WHC 1994e) is described in the Westinghouse Hanford Company Quality Assurance Program and Implementation Plan, WHC-SP-1131. The Westinghouse Hanford Company Quality Assurance Program and Implementation Plan, WHC-SP-1131, drives the development and use of the company-level quality assurance program, WHC-CM-4-2, which is used in conjunction with three subordinate manuals for TWRS activities.

Subordinate manuals include Quality Assurance Qualifications and Training, WHC-CM-4-5; TWRS Quality Management Plan, WHC-CM-6-34; and TWRS Quality Assurance Manual, WHCCM-6-50. The WHC-CM-6-34 and WHC-CM-6-50 are TWRS-specific, while WHC-CM-4-5 is WHC-wide. The WHC-CM-4-2 and the three subordinate manuals comprise the TWRS Quality Assurance program. Because CCS work is a major element of TWRS work in general, the Quality Assurance requirements for CCS work are the same as for TWRS work. Therefore, no refinement, exception, nor addition must made to the TWRS Quality Assurance program to accommodate CCS work. The document hierarchy for quality assurance is depicted in Figure 41.

Figure 4-1. Quality Assurance Document Hierarchy.

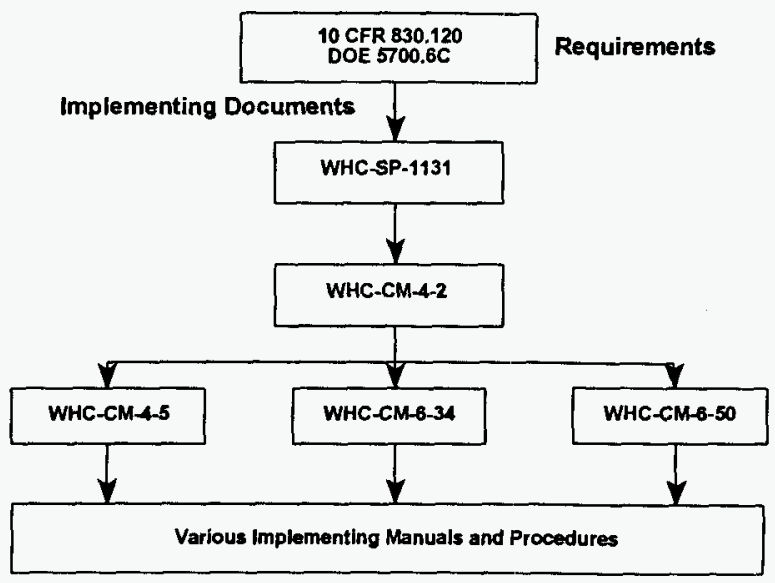


WHC-SD-WM-DRD-009, Rev 1

This page intentionally left blank. 
WHC-SD-WM-DRD-009, Rev 1

\subsection{PREPARATION FOR DELIVERY}

This section is not applicable to the CCS Project. 
WHC-SD-WM-DRD-009, Rev 1

This page intentionally left blank. 


\subsection{NOTES}

\subsection{INTENDED USE}

The intended use of CCS is to provide standard endpoint criteria that could be applied to all Single-Shell Tank Farms for long-term storage of the tanks, with minimum surveillance and maintenance costs.

\subsubsection{Missions}

The CCS Mission Goals are as follows:

- Reduce the 200 Area East and West Tank Farm Transition Projects operations and maintenance costs for the Single-Shell Tank Farm System by $50 \%$ within five years (based on the out-year projections contained in the Multi-Year Plan of September 1994);

- Operate the Single-Shell Tank Farms within the approved safety envelope (e.g., Interim Safety Basis, IOSR, and OSD requirements);

- Remove all pumpable tank interstitial liquids and exposed contaminated soil/debris from the Single-Shell Tank Farms; and

- Achieve compliance with near-term (pre-retrieval) regulatory requirements, defined through existing information and ongoing negotiations with regulatory agencies.

\subsubsection{Hazards}

The Nuclear Safety Analysis Reports, DOE Order 5480.23 (DOE 1992a), establishes requirements to develop safety analyses during design, construction, operation, maintenance, or decommissioning of DOE nuclear facilities. The purpose of safety analysis is to evaluate the adequacy of safety bases, and as a result, a Final Safety Analyses Report (FSAR) is generated. The hazards that may be associated with this project will be identified and documented in a FSAR for the system where the hazard is detected.

\subsection{DEFINITIONS}

This section provides definitions of the various terms that were used throughout this DRD.

\subsubsection{Accuracy}

In process instrumentation, accuracy is a degree of tolerance that errors will not exceed when a device is used under specified operation. 


\subsubsection{Controlled}

Controlled is the term used in CCS and its objectives are:

- Repair and/or upgrade of active and passive safety systems required to be operable by the safety basis authorization documents;

- Providing online monitoring capability for required instrumentation; and

- Implementation of the engineering and administrative controls necessary to comply with the safety basis authorization documents.

\subsubsection{Clean}

Clean is the term used in CCS and its objectives are:

- Clean-up of surface contamination to the extent necessary to downpost the Tank Farms to RBA, URMA, and/or RA status;

- Removal and disposal of above-ground abandoned equipment; and

- Placement of reusable equipment in environmentally compliant storage.

\subsubsection{Drainable Interstitial Liquid}

The DIL is interstitial liquid in a waste tank that is not held in place by capillary forces, and will therefore migrate or move with gravity.

\subsubsection{Enraf}

The Enraf Model 844ATG gauge, fabricated by Enraf, Inc., of Houston, TX, determines the waste level by detecting variations in the weight of a displacer suspended in the tank waste. The displacer is connected to a wire wound onto a precision measuring drum. A level causes a change in the displacer weight, which will be detected by the force transducer. Electronics within the gauge cause the servo motor to adjust the position of the displacer drum.

\subsubsection{High-Heat Tank}

The SSTs having more than 40,000-BTU/hr heat generated within waste are designated highheat tanks. These tanks require special monitoring requirements.

\subsubsection{Intrusion Prevention}

Intrusion Prevention is the administrative designation reflecting the completion of the physical effort required to minimize the addition of liquids into an inactive storage tank, process vault, sump, catch tank, or diversion box.

\subsubsection{Isokinetic}

Isokinetic is the collection of a particulate air sample by setting the sample probe inlet velocity equal to the velocity of the air stream being sampled. 
WHC-SD-WM-DRD-009, Rev 1

\subsubsection{Operable}

A system, subsystem, train, component, or device shall be 'operable' when it is capable of performing its specified safety function(s).

\subsubsection{Range}

Range is defined as the region between the limits within which a quantity is measured, received, or transmitted, expressed by stating the lower- and upper-range values.

\subsubsection{Repeatability}

Repeatability is the closeness of agreement among a number of consecutive measurements of the output, for the same value of the input under the same operating conditions, approaching from the same direction, for full-range transverse.

\subsubsection{Resolution}

Resolution is the least interval between two adjacent discrete details that can be distinguished one from the other.

\subsubsection{Stable}

Stable is the term used in CCS and its objectives are:

- Removal of pumpable interstitial liquid from SSTs and IMUSTs to comply with interim stabilization criteria; and

- Isolation of SST and IMUST systems to comply with intrusion prevention criteria.

\subsubsection{Supernate}

Supernate is the component of waste that is liquid in form and contains no appreciable suspended solids. The specific gravity of supernatant is approximately equal to, or slightly greater than, 1. The clear liquid floating on the tank waste surface is termed 'supernatant'. Tank supernatant levels are usually derived by subtracting the solids level measurement from the liquid level measurement; however, in some cases, this includes any floating solid crusts that are present in the tank.

\subsubsection{Thermocouple}

A thermocouple is a thermoelectric device used to measure temperature. More than one thermocouple on a device (probe) is called a thermocouple tree. These thermocouple trees monitor temperature gradients within the concrete walls, boftom of the tank, and the domes. In SSTs, one or more thermocouples may be installed directly in a tank, although some SSTs do not have any trees installed. A single thermocouple (probe) may be installed in a riser, or lowered into an existing riser. 
WHC-SD-WM-DRD-009, Rev 1

\subsubsection{Watch-List Tank}

A single-shell or double-shell high-level nuclear waste tank at the Hanford Site, Richland, Washington, that in accordance with Public Law 101-510, Section 3137, Safety Measures for Waste Tanks at Hanford Nuclear Reservation (U.S. Congress 1990), has been identified by the U.S. DOE Secretary of Energy as having serious potential for release of highlevel waste because of an uncontrolled increase of temperature or pressure.

\subsection{ABBREVATIONS AND ACRONYMS}

The acronyms and abbreviations provided in this section are used in this document.

\begin{tabular}{ll} 
ALARA & As Low As Reasonably Achievable \\
ANSI & American National Standards Institute \\
CAM & Continuous Air Monitor \\
CCS & Controlled, Clean, and Stable \\
CFR & Code of Federal Regulations \\
DAC & Derived Air Concentration \\
DCG & Derived Concentration Guides \\
DCRT & Double-Contained Receiver Tanks \\
DIL & Drainable Interstitial Liquid \\
DOE & U.S. Department of Energy \\
DOE-HQ & U.S. Department of Energy, Headquarters \\
DOE-RL & U.S. Department of Energy, Richland Operations Office \\
DST & Double-Shell Tank \\
DPM & Disintegration Per Minute (Unit of Radioactivity Level Measurement) \\
ECOlogy & Washington State Department of Ecology \\
FSAR & Final Safety Analysis Report \\
IMUST(s) & Inactive, Miscellaneous Underground Storage Tank(s) \\
IOSR(s) & Interim Operating Safety Requirement(s) \\
ISB & Interim Safety Basis \\
LCO(S) & Limiting Conditions for Operation(s) \\
PNNL & U.S. Department of Energy's Pacific Northwest National Laboratory, operated by \\
& Battelle Memorial Instifute \\
QA & Quality Assurance \\
QAP & Quality Assurance Plan \\
RA & Radiation Area \\
RBA & Radiological Buffer Area \\
RCT & Radiological Control Technicians \\
SE & Systems Engineering \\
SST & Single-Shell Tank \\
TFTP & Tank Farm Transition Projects \\
TMACS & Temperature Monitoring and Control System \\
TWRS & Tank Waste Remediation System \\
URMA & Underground Radioactive Material Area \\
USQ & Unreviewed Safety Question \\
WAC & Washington Administrative Code \\
WHC & Westinghouse Hanford Company \\
& \\
\hline
\end{tabular}




\subsection{APPENDICES}

\subsection{PERFORMANCE ANALYSIS}

Performance Analysis, which provides a comparison between CCS specifications and the performance capabilities of the systems and equipment being used in the CCS Project, is shown in Table 7-1.

\subsection{OPEN ITEMS}

The following open items must be resolved:

1. Implement the elements of the Single-Shell Tank Interim Operational Safety Requirements, WHC-SD-WM-OSR-005 (WHC 1994b), that are required to be implemented by the latest TWRS Authorization Basis implementation Plan;

2. Implement the administrative controls specified in Operating Specifications for Watch-List Tanks, WHC-OSD-T-151-00030, Section 30.2 (WHC 1996d) for all Watch-List SSTs;

3. Implement the administrative controls specified in Operating Specifications for Single-Shell Waste Storage Tanks, WHC-OSD-T-151-00013, Section 13.3 (WHC 1995b) for all IMUSTs; and

4. The Tank Farms FSAR is being prepared, and will impact the CCS performance requirements. Specific requirements likely to be affected will not be known until the FSAR has been approved by the DOE, Headquarters (DOE-HQ). Following DOE-HQ approval, the DRD requirements should be revised to ensure consistency with the FSAR. 
Table 7-1. Performance Analysis Comparing Specifications and the Performance Capabilities of the Systems and Equipment Being Used in the CCS Project.

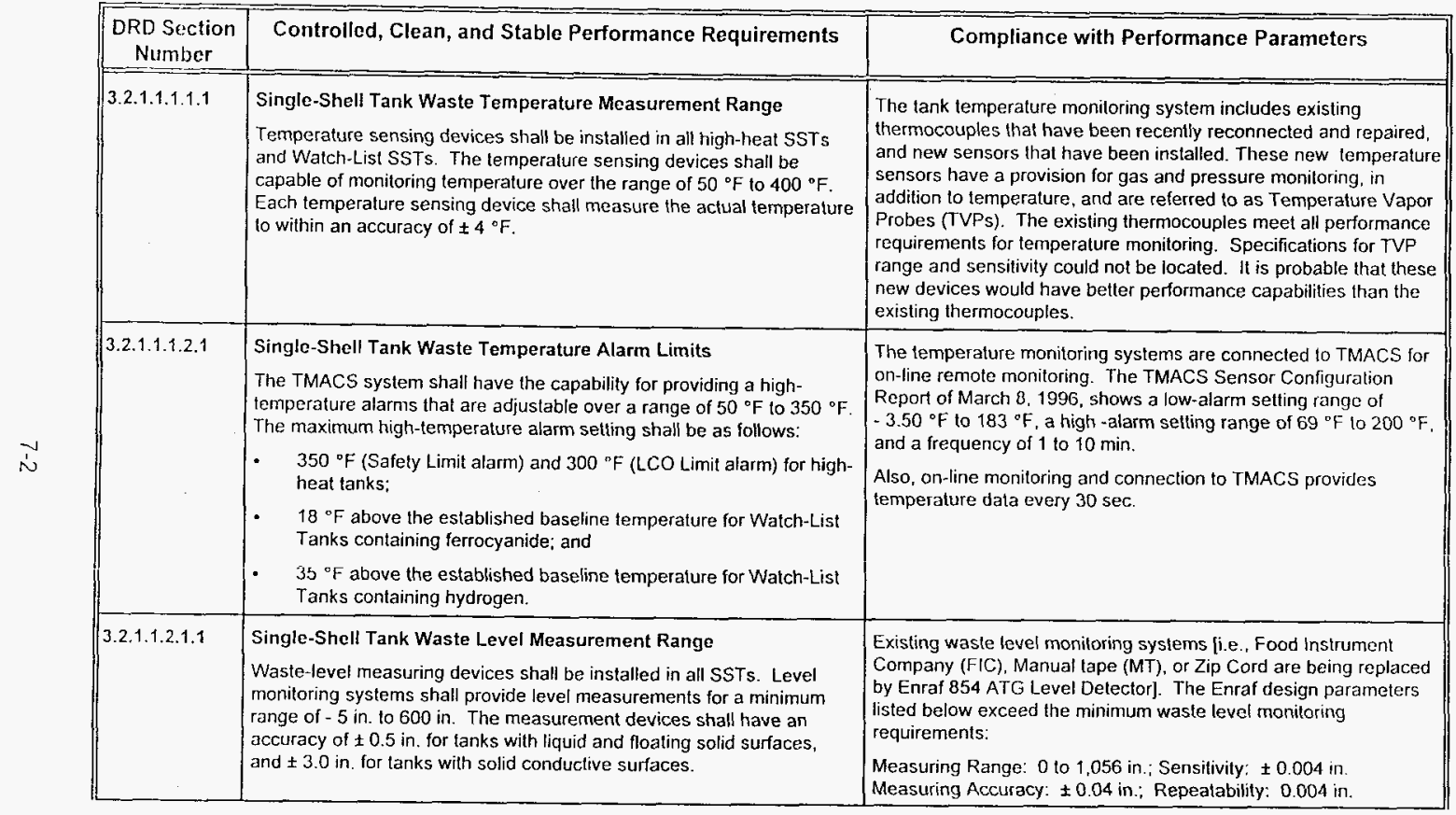


Table 7-1. Performance Analysis Comparing Specifications and the Performance Capabilities of the Systems and Equipment Being Used in the CCS Project.

\begin{tabular}{|c|c|c|}
\hline $\begin{array}{c}\text { DRD Section } \\
\text { Number }\end{array}$ & Controlled, Clean, and Stable Performance Requirements & Compliance with Performance Parameters \\
\hline 3.2 .1 .1 .2 .2 .1 & 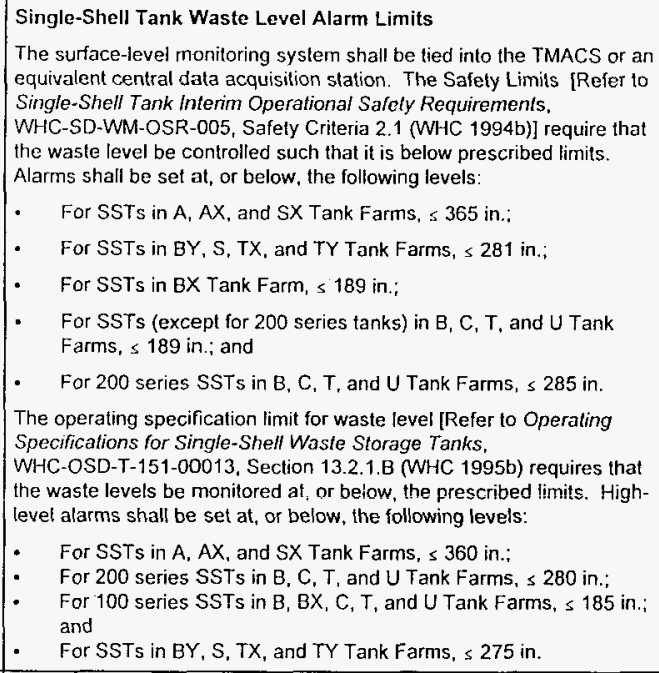 & $\begin{array}{l}\text { Surface level measurement devices such as Enrafs are connected } \\
\text { to TMACS for on-line remote monitoring. The TMACS provides } \\
\text { waste level dala every } 30 \text { sec. The TMACS Sensor Configuration } \\
\text { Report of March } 8,1996 \text {, shows a low-alarm setting range of } 0 \text { to } \\
398 \text { in., a high-alarm setting range of } 0 \text { to } 405 \text { in. Intrusion } \\
\text { detection alarms are set according to the waste level bascline, and } \\
\text { requirements are set for waste surface condition. }\end{array}$ \\
\hline 3.2 .1 .1 .3 .1 .1 & $\begin{array}{l}\text { Single-Shell Tank Intrusion Measurement Range } \\
\text { Tanik level measuring devices shall be installed in all SSTs. Level } \\
\text { monitoring systems shall provide level measurements for a minimum } \\
\text { range of }-5 \text { in. to } 600 \text { in. The measurement devices shall have an } \\
\text { accuracy of } \pm 0.5 \text { in. for tanks with liquid and floating solid surfaces, } \\
\text { and } \pm 3.0 \text { in. for tanks with solid conductive surfaces. }\end{array}$ & $\begin{array}{l}\text { Existing waste level monitoring systems [i.e., Food Instrument } \\
\text { Company (FIC), Manual tape (MT). or Zip Cord are being replaced } \\
\text { by Enraf } 854 \text { ATG Level Detector]. The Enraf design parameters } \\
\text { listed below exceed the minimum waste level monitoring } \\
\text { requirements: } \\
\text { Measuring Range: } 0 \text { to } 1,056 \text { in.; Sensitivity: } \pm 0.004 \text { in. } \\
\text { Measuring Accuracy: } \pm 0.04 \text { in.; Repeatability: } 0.004 \text { in. }\end{array}$ \\
\hline
\end{tabular}


Table 7-1. Performance Analysis Comparing Specifications and the Performance Capabilities of the Systems and Equipment Being Used in the CCS Project.

\begin{tabular}{|c|c|c|}
\hline $\begin{array}{c}\text { DRD Section } \\
\text { Number }\end{array}$ & Controlled, Clean, and Stable Performance Requirements & Compliance with Performance Parameters \\
\hline $3.2 .1 \cdot 1 \cdot 3.2 .1$ & $\begin{array}{l}\text { Single-Shell Tank Intrusion Level Alarm Limits } \\
\text { The surface levelintrusion monitoring system shall be tied into TMACS } \\
\text { or an equivalent central data acquisition station. } \\
\text { Alarm selpoints shall be adjustable from } 0 \text { in. to } 365 \text { in. Alarm settings } \\
\text { for Intrusion detection for different tank surfaces are specified in } \\
\text { Operating Specifications for Tank Fam Leak Defection and Singla- } \\
\text { Shell Tank Intrusion Detection (WHC 1995h); and Technical Bases for } \\
\text { Leak Defoction Surveillance of Waste Storage Tonks (WHC 1995g). } \\
\text { These setpoints shall be as follows: } \\
\text { a. Liquid Surface Tanks--A verified reading + } 0.5 \text { in. from the } \\
\text { reference baseline, or + } 1.0 \text { in. from the reference baseline for } \\
\text { tanks exhibiting significant seasonal variations; } \\
\text { b. Partial Liquid Surface--A verified reading + } 1.0 \text { in. from the } \\
\text { reference baseline; and } \\
\text { c. Conductive Solid Surface--A verified reading }+3.0 \text { in. from the } \\
\text { reference baseline. }\end{array}$ & $\begin{array}{l}\text { Surface level measurement devices such as Enrafs are connected } \\
\text { to TMACS for on-line remote monitoring. The TMACS provides } \\
\text { waste level data every } 30 \text { sec. The TMACS Sensor Configuration } \\
\text { Report of March } 8,1996 \text {, shows a low-alarm setting range of } 0 \text { to } \\
398 \text { in., a high-alarm selting range of } 0 \text { to } 405 \text { in. Intrusion } \\
\text { detection alarms are set according to the waste level baseline, and } \\
\text { requirements are set for waste surface condition. }\end{array}$ \\
\hline 3.2 .1 .1 .4 .1 .1 & $\begin{array}{l}\text { Single-Shell Tank Vapor-Space Measurement Range } \\
\text { Tank pressure monitoring systems shall be installed and operable for } \\
\text { actively ventilated SSTs. The pressure monitoring system shall provide } \\
\text { vapor-space pressure over a minimum range of }-15 \text { - to } 0 \text {-in. water } \\
\text { gauge with a resolution of } 0.1 \text {-in. water gauge, and accuracy of } \\
\pm 0.1 \text {-in. water gauge. }\end{array}$ & $\begin{array}{l}\text { The requirements for pressure monitoring on Watch-List and } \\
\text { ventilated SSTs are being reviewed. There are plans to add } \\
\text { pressure monitoring via a port on the Enraf level-gauge spool } \\
\text { piece, and read the pressure transmitter through an electronic } \\
\text { interface card within the level gauge. Technical feasibility of this } \\
\text { option is presently being investigated. } \\
\text { in addition, new TVPs have provision for gas and pressure } \\
\text { monitoring. The TVP range and sensitivity specifications could not } \\
\text { be located. It is probable that these new devices would have better } \\
\text { performance capabilities than the existing system. }\end{array}$ \\
\hline
\end{tabular}


Table 7-1. Performance Analysis Comparing Specifications and the Performance Capabilities of the Systems and Equipment Being Used in the CCS Project.

\begin{tabular}{|c|c|c|}
\hline $\begin{array}{c}\text { DRD Suction } \\
\text { Number }\end{array}$ & Controlled, Clean, and Stable Performance Requirements & Compliance with Performance Parameters \\
\hline 3.2 .1 .1 .4 .2 .1 & 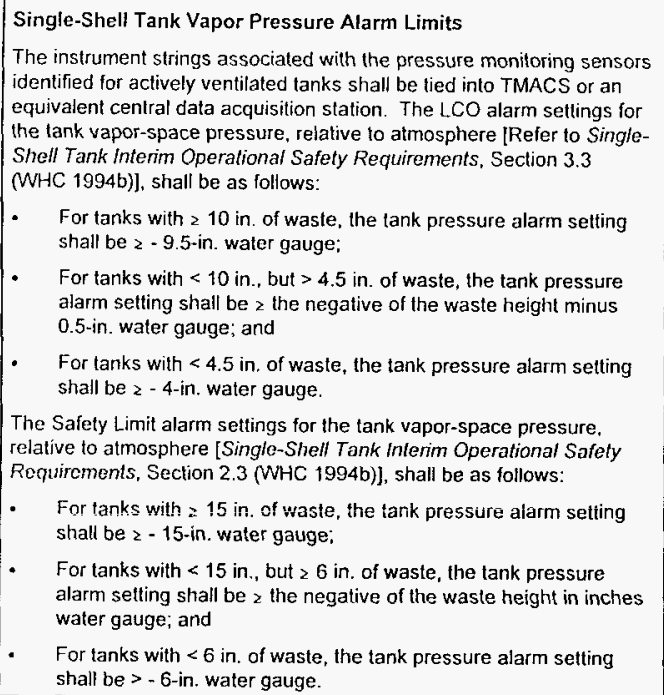 & $\begin{array}{l}\text { Requirements for pressure monitoring of Watch-List and activeiy } \\
\text { ventilated SSTs are being roviewed. There are plans to add } \\
\text { pressure monitoring via a port on the Enraf level-gauge spool } \\
\text { piece, and read the pressure transmitter through an electronic } \\
\text { interface card within the level gauge. Technical feasibility of this } \\
\text { option is presently being investigated. Pressure monitoring via the } \\
\text { TMACS will be accomplished by connection of TVPs and Enrats to } \\
\text { the system. }\end{array}$ \\
\hline
\end{tabular}


Table 7-1. Performance Analysis Comparing Specifications and the Performance Capabilities of the Systems and Equipment Being Used in the CCS Project.

\begin{tabular}{|c|c|c|}
\hline $\begin{array}{c}\text { DRD Section } \\
\text { Number }\end{array}$ & Controlled, Clean, and Stable Performance Requirements & Compliance with Performance Parameters \\
\hline 3.2 .1 .1 .5 .1 .1 & 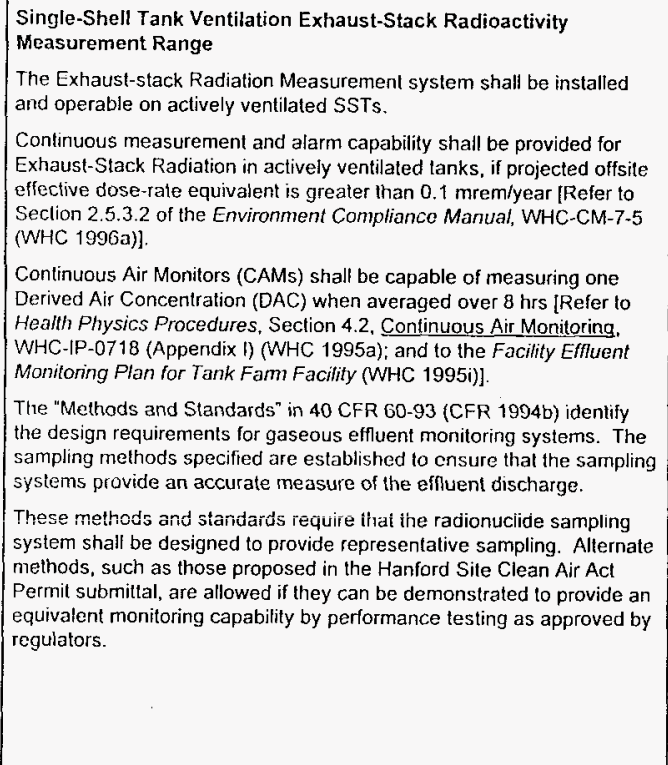 & 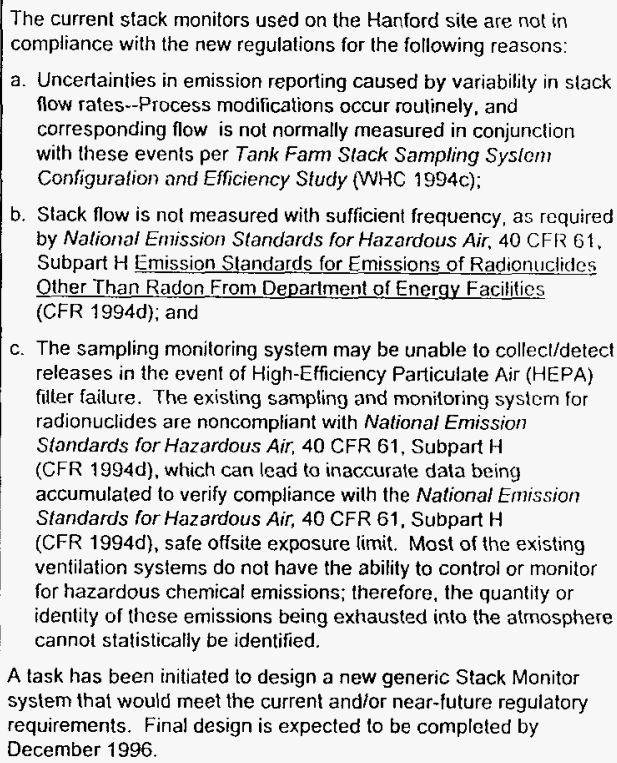 \\
\hline
\end{tabular}


Table 7-1. Performance Analysis Comparing Specifications and the Performance Capabilities of the Systems and Equipment Being Used in the CCS Project.

\begin{tabular}{|c|c|c|}
\hline $\begin{array}{c}\text { DRD Section } \\
\text { Number }\end{array}$ & Controlled, Clean, and Stable Performance Requirements & Compliance with Performance Parameters \\
\hline 3.2.1.1.5.2.1 & $\begin{array}{l}\text { Single-Shell Tank Gaseous Effluent Discharge Alarm Limits } \\
\text { The CAMs shall provide an alarm(s) on the TMACS Operator Console, } \\
\text { or an equivalent remote monitoring system. } \\
\text { Exhaust-stack radiation monitoring systems shall have the capability to } \\
\text { alarm at predefined setpoints [Refer to Environmental Compliance } \\
\text { Manual, WHC-CM-7-5 (WHC 1996a)]. Alarm setpoints shall be set to } \\
\text { the values specified in the Facility Effuent Moniforing Plan for the Tank } \\
\text { Fam Facility (WHC 1995i). } \\
\text { The CAM alarm setpoints are set by Radiological Control Technicians } \\
\text { (RCTs) by the procedure specified in Heallh Physics Procedures, } \\
\text { WHC-IP-0718, Appendix I. Section } 4.2 \text { (WHC 1995a). }\end{array}$ & $\begin{array}{l}\text { The Environmental Compliance Manual (WHC 1996a) is used for } \\
\text { environmental compliance purposes. The exhaust-stack alarm } \\
\text { setpoints will be set to the values specified in the Facility Effluent } \\
\text { Monitoring Plan for the Tank Farm Facility (WHC 1995i). } \\
\text { Exhaust-stack radiation moniloring and CAM alarm systems are } \\
\text { currently not connected to TMACS. }\end{array}$ \\
\hline 3.2 .1 .2 .1 & $\begin{array}{l}\text { Data Information Management } \\
\text { The TMACS System Performance Requirements shall be as follows: } \\
\text { a. Logging (disk) } \\
2,500 \text { points at } 30 \text {-min intervals; } \\
200 \text { points at } 10-\mathrm{sec} \text { intervals; and } \\
1,000 \text { points at } 5 \text {-min intervals. } \\
\text { b. Operator interface } \\
\text { A minimum of two active operator interfaces; } \\
\text { Display call up in } 3 \text { sec or less; and } \\
\text { Dynamic update of } 20 \text { variables per display every } 5 \text { sec. } \\
\text { c. Poiling and Alarm checking } \\
200 \text { points at } 10 \text { sec intervals; } \\
1,000 \text { points at } 1 \text {-min intervals; and } \\
3,800 \text { points at } 10 \text {-min intervals. } \\
\text { d. Trends } \\
20 \text { real-time trend displays each with three variables; and } \\
\text { All variables trending at } 1 \text {-min periods. }\end{array}$ & $\begin{array}{l}\text { The TMACS System Performance Parameters will be as follows: } \\
\text { a. Logging (disk) } \\
\text { Current logging capability are in compliance with the } \\
\text { requirements; } \\
\text { b. Operator interface } \\
\text { Current operator interface is in compliance with the } \\
\text { requirements; } \\
\text { c. Polling and Alarm checking } \\
\text { The current polling and alarm checking is at } 25 \text { points/sec; and } \\
\text { d. Trends } \\
\text { Real-time trend displays are currently at } 10 \text {. } \\
\text { All variables are trending at } 10 \text {-min periods. } \\
\text { The TMACS will process incoming data within } 15 \% \text { of its CPU } \\
\text { capacity. }\end{array}$ \\
\hline
\end{tabular}


Table 7-1. Performance Analysis Comparing Specifications and the Performance Capabilities of the Systems and Equipment Being Used in the CCS Project.

\begin{tabular}{|c|c|c|}
\hline $\begin{array}{l}\text { DRD Section } \\
\text { Number }\end{array}$ & Controlled, Clean, and Stable Performance Requirements & Compliance with Performance Parameters \\
\hline 3.2 .1 .3 .1 .1 & $\begin{array}{l}\text { Provide intrusion Prevention of Interim Stabilized Tanks } \\
\text { The following criteria shall be followed: } \\
\text { a. Risers terminating above-grade or less than } 3 \mathrm{ft} \text { below-grade shall } \\
\text { be sealed; and } \\
\text { b. Pits, cells, and vaults for lanks with risers/piping systems terminating } \\
\text { in a confined area shall be installed and sealed. }\end{array}$ & $\begin{array}{l}\text { Interim Isolation will be documented per the Confirmation of Interim } \\
\text { Isolation Checksheet, as required per the Tank Waste } \\
\text { Remediation Systom Administration Manual, WHC-IP-0842, } \\
\text { Volume IV. Section } 4.2 \text { (WHC 1995e). The checklist has ficld } \\
\text { verification of the activities required for interim isolation. }\end{array}$ \\
\hline 3.2 .1 .3 .2 .1 & $\begin{array}{l}\text { Categorize Out-of-Service, Reusable, and Inaccessible Out-of- } \\
\text { Service Equipment } \\
\text { The categorized equipment shall be dispositioned per the Management } \\
\text { of Contaminated Equipment at the Hanford Site (DOE-RL 1995); and } \\
\text { the TWRS Abandoned Equipment Storage/Disposal Plan } \\
\text { WHC 1995d). Above-ground, out-of-service contaminated equipment } \\
\text { that is not reusable and is inaccessible or difficult to remove (based on } \\
\text { the risk and cost involved) shall be sealed to prevent contamination } \\
\text { spread, in accordance wilh Section } 3.2 .13 .1 .1 \text {. } \\
\text { All above-ground, out-of-service contaminated equipment that is not } \\
\text { reusable shall be inventoried and dispositioned. Dispositioning in most } \\
\text { cases will require characterizing the waste constituents, removing and } \\
\text { packaging the equipment as waste, and designating the waste } \\
\text { containers in accordance with WAC 173-303 (WAC 1995a). } \\
\text { Reusable contaminated equipment shall be managed in accordance } \\
\text { with as-low-as-reasonably-achievable (ALARA) guidelines and the } \\
\text { WAC } 173-303 \text { (WAC 1995a) requirements relevant to storage of } \\
\text { dangerous wastes (where appropriate). This will provide } \\
\text { Environmentally Compliant Storage for Reusable Equipment. }\end{array}$ & $\begin{array}{l}\text { a. Above-ground, out-of-service equipment that is no longer } \\
\text { intended for future use, or that has been abandoned in-place. } \\
\text { shall be assessed for physical disconnection, packaging, } \\
\text { characterization, and segregation for disposal. The necessity of } \\
\text { physical disconnection and removal of installed out-of-scrvice } \\
\text { equipment shall be determined on a case-by-case basis. } \\
\text { Dangerous waste components shall be designated and } \\
\text { transported to a permitted Treatment, Storage, and Disposal } \\
\text { facility. } \\
\text { b. Reusable equipment that has a current and/or future purpose or } \\
\text { function and is not intended for discard will be inventoried and } \\
\text { stored for fulure use. Highly radioactive equipment will be } \\
\text { shielded or stored in such a way to minimize personnel radiation } \\
\text { exposure. Equipment that had been in contact with tank waste } \\
\text { will be stored in an appropriate containment device/container to } \\
\text { prevent release of dangerous waste to the environment. } \\
\text { c. Out-of-service/abandoned equipment that is inaccessible by } \\
\text { plan or design shall be isolated/sealed to prevent contamination } \\
\text { to the environment. In general, equipment that is below-grade } \\
\text { (i.e., pump and transfer pit) shall be dispasitioned under RCRA } \\
\text { closure of the SSTs, and will not be removed as part of CCS, } \\
\text { unless it poses a significant personnel exposure and/or } \\
\text { environmental hazard. }\end{array}$ \\
\hline
\end{tabular}


Table 7-1. Performance Analysis Comparing Specifications and the Performance Capabilities of the Systems and Equipment Being Used in the CCS Project.

\begin{tabular}{|c|c|c|}
\hline $\begin{array}{c}\text { DRD Section } \\
\text { Number }\end{array}$ & Controlled, Clean, and Stable Performance Requirements & Compliance with Performance Parameters \\
\hline 3.2 .1 .3 .3 .1 & $\begin{array}{l}\text { Reduce Surface-Soil Contamination and Radiation Levels in the } \\
\text { Single-Shell Tank Farms } \\
\text { The following requirements shall be as follows: } \\
\text { Surface contamination levels shall be reduced to less than } 5,000 \mathrm{DPM} \\
\text { (Beta/Gamma) per } 100 \mathrm{~cm}^{2} \text { direct (fixed and removable) and less than } \\
1,000 \mathrm{DPM} \text { (Beta/Gamma) per } 100 \mathrm{~cm}^{2} \text { removable. } \\
\text { Radiation levels shall be less than } 100 \mathrm{mrem} / \mathrm{hr} \text { at a distance of } 30 \mathrm{~cm} \\
\text { or } 12 \mathrm{in.} \text { from the radiation source. }\end{array}$ & $\begin{array}{l}\text { Contaminated surface soils will be removed and/or stabilized by } \\
\text { excavation, scraping, and/or resurfacing. To reduce contamination } \\
\text { and radiation levels, a grid survey will be performed and } \\
\text { documenled on a Radiological Survey Report Form (Form BD- } \\
6000-010) \text {. A map of each grid will be included as a continuation } \\
\text { sheet (Form BD-6000-010.1R). The extent of the surface } \\
\text { remediation efforts will depend on contamination levels and } \\
\text { tank/riser configurations. }\end{array}$ \\
\hline 3.2 .1 .3 .3 .2 & $\begin{array}{l}\text { Prevent Migration of Below-Grade Contamination } \\
\text { Surface soil within SST farms shall be stabilized to prevent below-grade } \\
\text { contamination from migration to the surface. }\end{array}$ & $\begin{array}{l}\text { Gravel or a stabilizing agent will be applied to the soil surface after } \\
\text { surveying the Tank Farm per the Survey.Melhod for Reposting } \\
\text { Outdoor Contamination Areas checklist, in accordance with Heallh } \\
\text { Physics Procedures, WHC-IP-0718, Section } 3.1 .2 \text { (WHC 1995a). } \\
\text { Gravel or other approved soil stabilizing agents will be applied } \\
\text { after, or in place of, excavation, depending on contamination levels } \\
\text { and depth. }\end{array}$ \\
\hline $3.2 .1,3.3 .3$ & $\begin{array}{l}\text { Establish Access Controls } \\
\text { Access into the SST farms shall be restricted by establishing } \\
\text { administrative and physical controls, as required by Occupational } \\
\text { Radiaton Protection, 10 CFR } 835.603 \text { (CFR 1993), and by Dangerous } \\
\text { Waste Regulations. Section } 310 \text { (WAC 1995a). The controls } \\
\text { established will depend on the classification of the tank farm boundary } \\
\text { (i.e., URMA, RBA, RA). }\end{array}$ & $\begin{array}{l}\text { A grid survey will be performed within Tank Farm perimeters for } \\
\text { downposting, per the Survey Method for Reposting Outdoor } \\
\text { Coniamination Areas checklist, in accordance with W Health } \\
\text { Physics Procedures, WHC-IP-0718, Section } 3.1 .2 \text { (WHC 1095a). } \\
\text { The Radiological Control manager will review the survey data and } \\
\text { determine if the scope and results of the survey support } \\
\text { downposting the area. Administrative and engineering controls } \\
\text { (t.e. procedure, signs, fences, or alarms) will then be installed to } \\
\text { control access into the Tank Farm. }\end{array}$ \\
\hline
\end{tabular}


Table 7-1. Performance Analysis Comparing Specifications and the Performance Capabilities of the Systems and Equipment Being Used in the CCS Project.

\begin{tabular}{|c|c|c|}
\hline $\begin{array}{c}\text { DRD Section } \\
\text { Number }\end{array}$ & Controlled, Clean, and Stable Performance Requirements & Compliance with Performance Parameters \\
\hline 3.2 .1 .4 .1 .2 & $\begin{array}{l}\text { Interim Stabilize } 200 \text { East Area Single-Shell Tanks } \\
\text { Liquids from non-interim-stabilized } 200 \text { East Area SSTs shall be } \\
\text { pumped and transferred to } 200 \text { East Area DSTs. Each tank shall be } \\
\text { pumped until the specifications (criteria) provided in the Tank Waste } \\
\text { Remediation System Administration Manual, WHC-IP-0842, Volume IV, } \\
\text { Section } 4.1 \text { (WHC 1995e) have been satisfied. } \\
\text { The final acceptance criteria for SST interim stabilization are as follows: } \\
\text { a. Each tank contains less than } 50,000 \text { gal of DIL, based on either a } \\
45 \% \text { porosity, or on the porosity determined during actual pumping: } \\
\text { b. Each tank contains less than } 5,000 \text { gal of supernatant; and } \\
\text { c. The pumping rate has decreased to less than } 0.05 \text { gal/min, or inflow } \\
\text { in the saltwell screen has decreased to less than } 0.05 \text { gal/min, and } \\
\text { the tank has less than } 50,000 \text { gal of DIL remaining. }\end{array}$ & $\begin{array}{l}\text { Interim stabilization will be documented per the Single-Shell Tank } \\
\text { Interim Stabilization Evaluation forms, as required per the Tank } \\
\text { Waste Remedialion System Administration Manual, WHC-IP-0842, } \\
\text { Volume IV, Section } 4.1 \text { (WHC 1995e). The checklist provides field } \\
\text { verification of the activities required for interim stabilization. }\end{array}$ \\
\hline 3.2 .1 .4 .2 .2 & $\begin{array}{l}\text { Interim Stabilize } 200 \text { West Area Single-Shell Tanks } \\
\text { Liquids from non-interim-stabilized } 200 \text { West Area SSTs shall be } \\
\text { pumped and transferred to } 200 \text { West Area DSTs. Each tank shall be } \\
\text { pumped until the specifications (criteria) provided in the Tank Waste } \\
\text { Remediation System Administration Manual, WHC-IP-0842, Volume IV, } \\
\text { Section } 4.1 \text { WHC } 1995 \text { ), have been satisfied. Final acceptance } \\
\text { criteria for interim stabilization of SSTs are as follows: } \\
\text { a. Each tank contains less than } 50,000 \text { gal of DIL, based on either a } \\
45 \% \text { porosity, or on the porosity determined during actual pumping; } \\
\text { b. Each tank contains less than } 5,000 \text { gal of supernatant; and } \\
\text { c. Pumping rate has decreased to less than } 0.05 \text { gal/min, or if inflow in } \\
\text { the saltwell screen has decreased to less than } 0.05 \text { gal/min, and the } \\
\text { tank has less than } 50,000 \text { gal of DIL remaining }\end{array}$ & $\begin{array}{l}\text { Interim stabilizalion will be documented per the Single-Shell Tank } \\
\text { Interim Stabilization Evaluation forms, as required per the Tank } \\
\text { Waste Remediation Systcm Administration Manual, WHC-AP-0842 } \\
\text { Volume IV. Seclion } 4.1 \text { (WHC 1995e). The checklist provides field } \\
\text { verification of the activities required for interim stabilization. }\end{array}$ \\
\hline
\end{tabular}


Table 7-1. Performance Analysis Comparing Specifications and the Performance Capabilities of the Systems and Equipment Being Used in the CCS Project.

\begin{tabular}{|l|l|l|}
\hline $\begin{array}{l}\text { DRD Section } \\
\text { Number }\end{array}$ & Controlled, Clean, and Stable Performance Requirements & Compliance with Performance Parameters \\
\hline 3.2 .1 .5 .1 & $\begin{array}{l}\text { Interim Stabilize Inactive Miscellaneous Underground Storage } \\
\text { Tanks } \\
\text { The waste transfer system shall be capable of transferring 121,772-gal } \\
\text { pumpable liquid waste. Each tank shall be pumped until: } \\
\text { a. Tanks containing low-level radioactive supernatant liquid shall be } \\
\text { pumped to 400 gal or less (4 in. or less from the bottom of the } \\
\text { solids/sludge level); and } \\
\text { b. Tanks containing more than 5,000-gal highly radioactive supernatant } \\
\text { shall be pumped down via overground piping to an underground } \\
\text { lank (not SST) or receiver vessel where tank trucks cannot be used } \\
\text { without dilution. }\end{array}$ & $\begin{array}{l}\text { Interim stabilization will be documented per the Interim Stabilization } \\
\text { Evaluation Forms, as required per the Tank Waste Remediation } \\
\text { Section 4.1 (WHC 1995e). The checklist provides field verification } \\
\text { of the activities required for interim stabilization. }\end{array}$ \\
\hline
\end{tabular}

